(2) Open Access Full Text Article

REVIEW

\title{
Stem cells for luminal, fistulizing, and perianal inflammatory bowel disease: a comprehensive updated review of the literature
}

This article was published in the following Dove Press journal:

Stem Cells and Cloning:Advances and Applications

\author{
Erica P Turse \\ Francis E Dailey \\ Maliha Naseer \\ Edward K Partyka \\ Jack D Bragg \\ Veysel Tahan
}

Department of Internal Medicine, Division of Gastroenterology and Hepatology, University of Missouri Health Center, Columbia, MO 65212, USA
Correspondence: Veysel Tahan Department of Internal Medicine, Division of Gastroenterology and Hepatology, University of Missouri, I Hospital Drive, CD 405, Columbia, MO 65212, USA

Tel +I 5738846044

Fax +I 5738844595

Email tahanv@health.missouri.edu

\begin{abstract}
Much research has been performed over the last decade on stem cell therapy as treatment for patients with inflammatory bowel disease. Hematopoietic and mesenchymal stem cells, both allogeneic (from someone else) and autologous (from own patient), have been studied with safe and efficacious results in the majority of patients treated for luminal, perianal, and/or fistulizing disease. Here in this review, we highlight all human trials that have been conducted utilizing stem cell therapy treatment in patients with inflammatory bowel disease.
\end{abstract}

Keywords: inflammatory bowel disease, Crohn's disease, ulcerative colitis, mesenchymal, hematopoietic, autologous, allogeneic, therapy, treatment

\section{Introduction}

Inflammatory bowel disease (IBD) is a unique spectrum of disease processes, which includes ulcerative colitis (UC), Crohn's disease (CD), and indeterminate colitis (IC). Unfortunately, incidence and prevalence of these diseases is on the rise worldwide including low-incidence regions of China, India, Japan, North Africa, Middle East, South Korea, Thailand, as well as 1.3 million people in the United States and 2.4 million in Europe. ${ }^{1}$ The exact mechanism of recurrence of these diseases is unknown. Yet, IBD is known to be autoimmune in nature and characterized by T-cell infiltration to the colon and small bowel. Recently, there has been a new interest in using stem cell therapy given its immunosuppressive capabilities toward treating refractory IBD. One of the reasons those with IBD experience symptoms is due to severe inflammation leading to epithelial cell death and extracellular matrix destruction. By using stem cell transplantation, the damaged intestinal barrier is able to undergo regeneration using multipotent stem cells. ${ }^{2}$

Given there are several types of stem cells used for the treatment of IBD such as hematopoietic stem cells (HSC) vs mesenchymal stem cells (MSC), and research uses either treatment for luminal vs perianal vs fistulizing disease, this review will be outlined as such. Cells can either be autologous or allogeneic in nature, meaning they are either obtained from the individual's cells or harvested from another individual's cells, respectively. HSC are cells that are infused which can develop into a variety of blood cell types including T-lymphocytes with the thought that they "reset" the immune system of the IBD patient. ${ }^{3}$ MSC are either derived from bone marrow or adipose tissue with fibroblast-like morphology, lacking the expression of hematopoietic markers and retaining the ability to undergo pluripotent transformation into cells such as 
adipocytes, osteoblasts, or chondroblasts. ${ }^{1}$ Interestingly, both HSC and MSC have been studied and used in the treatment of IBD due to their immunosuppressive potentials, which will be discussed here.

A literature search was performed by a gastroenterology fellow of PubMed and ClinicalTrials.gov through May 2018 using the subject headings "inflammatory bowel disease", "Crohn's disease", "ulcerative colitis", and "stem cell therapy". The searches were limited to the English language, and excluded letters, editorials, comments, and case reports. Articles that were known to the authors and retrieved articles from review of the above articles' references were also included.

\section{Stem cell therapy for luminal IBD}

Luminal disease is the most common presentation of IBD. $\mathrm{CD}$ is defined by inflammation from mouth to anus with the presence of skip lesions of the lumen and transmural inflammation. On the contrary, UC traditionally has continuous inflammation commonly only to the mucosa and submucosa and only involves the colon. Luminal disease has been treated with a broad variety of medications including antibiotics, immunomodulators, and biologics. Unfortunately, despite the progression of available medical treatments, patients still have refractory disease. This is where stem cell therapy has been proposed as a novel treatment. An overview of stem cell therapies for luminal disease can be seen outlined in Table 1.

\section{Hematopoietic-derived stem cell therapy trials}

The mechanism of action of hematopoietic-derived stem cell therapy (HSCT) involves resetting of the primary immune system (restoration) by eliminating T-lymphocytes via lymphoablation using chemotherapy followed by reconstitution of the immune system with more naïve and tolerogenic lymphocytes. In this process, the genetic predisposition of the patient is not modified. Hence, the patient is at risk of having recurrent disease. ${ }^{4}$ In contrast, allogeneic HSCT (alloHSCT) involves correcting patient genetic predisposition by replacement of the immune system with the donor immune system. However, alloHSCT is not currently approved for the management of $\mathrm{CD}$ due to high risk of side effects and mortality associated with the treatment. ${ }^{5}$ Autologous HSCT (autoHSCT) in patients with luminal CD should be considered in patients with severe disease, refractory to conventional medical treatment in whom surgery is not possible because of the extent of the disease or previous resections. $^{6}$
HSCT for IBD was first described in 1993 in a case report where a patient who underwent transplant for lymphoma was incidentally noted to have benefits for active Crohn's colitis. ${ }^{7}$ This event prompted further research. In 2005, Oyama et al reported a Phase I autoHSCT trial including a series of 12 patients with severe CD (Crohn's Disease Activity Index [CDAI] of 250-400) who failed standard treatment protocols including biological agents. ${ }^{8}$ In all patients, there was improvement in the CDAI score immediately after autoHSCT. However, endoscopic resolution of intestinal inflammation was more gradual. Approximately 92\% (11 out of 12) of the patients had sustained remission after median follow-up of 18.5 months. In all these studies, the authors performed mobilization of peripheral blood stem cells with immunosuppressive (cyclophosphamide) and granulocyte colony-stimulating factor (G-CSF) and CD34+ selection. ${ }^{8}$

Additionally, there was a study published by Cassinotti et al in 2008 on patients with active moderate-severe CD with HSCT without CD34+ selection. ${ }^{9}$ Included were four Caucasian patients with active moderate-severe CD with CDAI $>250$ and refractory disease after cyclophosphamide (CTX), G-CSF, and HCST. Patients were given standard supportive care as mentioned above. Clinical remission was defined by the authors as CDAI $<150$ without symptoms for 1 month, and clinical response was a decrease in CDAI by 100 points. Additionally, endoscopic remission was included and defined as complete absence of mucosal lesions at examination. All four subjects reported improvement in their symptoms at the time of discharge 1 month after transplantation. Medical therapy was not uniform in these patients with topical mesalamine being continued in one patient, and antibiotics used for fistulas continued as well. Overall, autoHCST was tolerated with all patients achieving complete clinical remission within the third month with a median CDAI of 91. Unfortunately, one patient was not able to have endoscopic mucosal evaluation given the location of his ileal disease. However, the other three patients showed mucosal healing and endoscopic remission after transplant. At the end of the study 16.5 months later, median CDAI was 82 . The primary end point of the study was achieved with clinical remission being attained in all patients and endoscopic remission was achieved in $>90 \%$ of the patients after a median follow-up of 16.5 months. ${ }^{9}$

In 2010, a Phase I/II study on the long-term efficacy of autoHSCT was authored by Burt et al. ${ }^{10}$ They utilized autologous nonmyeloablative HSCT in patients with severe CD based on CDAI $>250$ or Crohn Severity Index (CSI) $>16$. Patients had a wide array of luminal, perianal, and fistulizing disease. There were 25 patients enrolled with one 
Table I Overview of stem cell studies for treatment with patients having luminal disease

\begin{tabular}{|c|c|c|c|c|c|c|}
\hline Author & Date & $\begin{array}{l}\text { Stem cell } \\
\text { type }\end{array}$ & $\begin{array}{l}\text { Treatment } \\
\text { location }\end{array}$ & Study type & Patients (n) & Results \\
\hline Oyama et al ${ }^{8}$ & 2005 & HSCT & Luminal & $\begin{array}{l}\text { Phase I } \\
\text { Retrospective }\end{array}$ & 12 & $\begin{array}{l}92 \% \text { remission rates after } 18.5 \\
\text { months }\end{array}$ \\
\hline $\begin{array}{l}\text { Cassinotti } \\
\text { et } \mathrm{al}^{9}\end{array}$ & 2008 & HSCT & Luminal & Prospective & 4 & $\begin{array}{l}100 \% \text { remission by } 3 \text { months with } \\
\text { CDAI } 91 \text { and CDAI } 82 \text { after } 16.5 \\
\text { months }\end{array}$ \\
\hline Burt et al ${ }^{10}$ & 2010 & HSCT & Luminal & $\begin{array}{l}\text { Phase I/II } \\
\text { Prospective }\end{array}$ & $\begin{array}{l}24 \text { (initially } 25 \\
\text { but one patient } \\
\text { excluded) }\end{array}$ & $70 \%-80 \%$ remission at 5 years \\
\hline $\begin{array}{l}\text { Hommes } \\
\text { et al"I }\end{array}$ & 2011 & HSCT & Luminal & Prospective & $\begin{array}{l}3 \text { ( } 2 \text { with } \\
\text { mobilization+ } \\
\text { transplantation, I } \\
\text { with mobilization } \\
\text { only) }\end{array}$ & $\begin{array}{l}100 \% \text { remission at } 5-6 \text { years } \\
\text { posttransplant in mobilization+ } \\
\text { transplantation group } \\
\text { Patient with only mobilization had } \\
\text { relapse at } 2 \text { years }\end{array}$ \\
\hline $\begin{array}{l}\text { Hasselblatt } \\
\text { et } \mathrm{al}^{\prime 2}\end{array}$ & 2012 & HSCT & Luminal & $\begin{array}{l}\text { Phase I/II } \\
\text { Prospective }\end{array}$ & $\begin{array}{l}\text { I2 (II with cell } \\
\text { mobilization) }\end{array}$ & $\begin{array}{l}45.5 \% \text { remission after } 6 \\
\text { months, } 63.6 \% \text { with endoscopic } \\
\text { improvement }\end{array}$ \\
\hline $\begin{array}{l}\text { Snowden } \\
\text { et al }\end{array}$ & 2012 & HSCT & Luminal & Retrospective & 6 & $\begin{array}{l}\text { No mortality at } 50-123 \text { months } \\
\text { post transplant }\end{array}$ \\
\hline $\begin{array}{l}\text { Jauregi- } \\
\text { Amezaga } \\
\text { et } \mathrm{al}^{15}\end{array}$ & 2016 & HSCT & Luminal & $\begin{array}{l}\text { Prospective } \\
\text { Randomized }\end{array}$ & $\begin{array}{l}26 \text { (initially } \\
28 \text { with two } \\
\text { excluded) }\end{array}$ & SAE seen (infection most common) \\
\hline $\begin{array}{l}\text { López-Garcia } \\
\text { et } \mathrm{al}^{14}\end{array}$ & 2017 & HSCT & Luminal & Prospective & $\begin{array}{l}35 \text { total (initially } \\
37 \text { but } 2 \text { excluded) } \\
29 \text { patients } \\
\text { transplanted }\end{array}$ & $\begin{array}{l}70 \% \text { remission by } 6 \text { months } \\
73 \% \text { remission by } 12 \text { months } \\
93 \% \text { remission by } 3 \text { years } \\
70 \% \text { remission by } 4 \text { years } \\
100 \% \text { remission by } 5 \text { years } \\
65 \% \text { endoscopic healing at } 12 \\
\text { months }\end{array}$ \\
\hline $\begin{array}{l}\text { Hawkey } \\
\text { et al }{ }^{15}\end{array}$ & 2015 & HSCT & Luminal & $\begin{array}{l}\text { Prospective } \\
\text { Randomized }\end{array}$ & $\begin{array}{l}48 \text { mobilization } \\
\text { with and after } \\
\text { randomization } \\
23 \mathrm{HSCT}, 23 \\
\text { standard vs } 22 \\
\text { controls vs } 22 \\
\text { standard } \\
\end{array}$ & $\begin{array}{l}\text { SAE seen (infection most common) } \\
60.9 \% \text { HSCT group remission } 3 \\
\text { months vs } 22.7 \% \text { control } \\
34.8 \% \text { HSCT group CDAI }<150 \\
\text { last } 3 \text { months vs } 9.1 \% \text { control } \\
34.8 \% \text { HSCT group no disease on } \\
\text { imaging vs } 9.1 \% \text { control }\end{array}$ \\
\hline $\begin{array}{l}\text { Lindsay } \\
\text { et a }\left.\right|^{16}\end{array}$ & 2017 & HSCT & Luminal & $\begin{array}{l}\text { Prospective, } \\
\text { Open label, } \\
\text { Phase III, } \\
\text { Randomized }\end{array}$ & $\begin{array}{l}45 \text { with } 23 \text { HSCT } \\
\text { vs } 22 \text { mobilization } \\
\text { with standard care } \\
\text { with } 17 \text { of these } \\
\text { receiving HSCT } \\
\text { post prior study }\end{array}$ & $\begin{array}{l}57.5 \% \text { had SAE } \\
38 \% \text { remission of } 3 \text { month steroid } \\
\text { free at I year analysis } \\
50 \% \text { complete endoscopic healing }\end{array}$ \\
\hline Rabian et al ${ }^{17}$ & 2016 & HSCT & Luminal & Retrospective & $\begin{array}{l}\text { I8 patients with } \\
\text { IBD and I } 8 \\
\text { matched controls }\end{array}$ & $\begin{array}{l}39 \% \text { patients with graft vs host } \\
\text { disease } \\
19 \% \text { nonrelapse mortality }\end{array}$ \\
\hline Onken ${ }^{20}$ & 2008 & $\begin{array}{l}\text { Autologous } \\
\text { BMT }\end{array}$ & Luminal & $\begin{array}{l}\text { Prospective } \\
\text { Phase I }\end{array}$ & 10 & $\begin{array}{l}20 \% \text { with } 100 \text { point reduction } \\
\text { CDAI I week } \\
38 \% \text { patients with increased IBD } \\
\text { quotient scores in } 4 \text { weeks }\end{array}$ \\
\hline $\begin{array}{l}\text { Duijvestein } \\
\text { et } \mathrm{al}^{2 !}\end{array}$ & 2010 & $\begin{array}{l}\text { Autologous } \\
\text { BMT }\end{array}$ & Luminal & $\begin{array}{l}\text { Prospective } \\
\text { Phase I }\end{array}$ & $\begin{array}{l}9 \text { ( } 1 \text { excluded due } \\
\text { to no disease on } \\
\text { initial screening) }\end{array}$ & $\begin{array}{l}\text { Mean CDAI scores decreased } 70 \\
\text { from baseline to } 6 \text { weeks in five } \\
\text { patients (55\%) } \\
\text { Crohn's Disease Endoscopic Index } \\
\text { Score decreased } 10 \text { and } 24.7 \text { in } \\
\text { two patients } \\
\text { No significant endoscopic } \\
\text { improvement in five patients }\end{array}$ \\
\hline
\end{tabular}

(Continued) 
Table I (Continued)

\begin{tabular}{|c|c|c|c|c|c|c|}
\hline Author & Date & $\begin{array}{l}\text { Stem cell } \\
\text { type }\end{array}$ & $\begin{array}{l}\text { Treatment } \\
\text { location }\end{array}$ & Study type & Patients (n) & Results \\
\hline Dhere et $\mathrm{al}^{22}$ & 2016 & $\begin{array}{l}\text { Autologous } \\
\text { BMT }\end{array}$ & Luminal & $\begin{array}{l}\text { Prospective } \\
\text { Phase I }\end{array}$ & $\begin{array}{l}\text { II (I excluded } \\
\text { due to loss to } \\
\text { follow-up) }\end{array}$ & $\begin{array}{l}\text { Improved CDAI worsened CRPs } \\
63.6 \% \mathrm{SAE}\end{array}$ \\
\hline Liang et $\mathrm{a}^{23}$ & 2012 & $\begin{array}{l}\text { Allogeneic } \\
\text { BMT }\end{array}$ & Luminal & $\begin{array}{l}\text { Prospective } \\
\text { Phase II }\end{array}$ & 9 & $33.3 \%$ remission \\
\hline Forbes et $\mathrm{al}^{24}$ & 2014 & $\begin{array}{l}\text { Allogeneic } \\
\text { BMT }\end{array}$ & Luminal & $\begin{array}{l}\text { Prospective } \\
\text { Phase II }\end{array}$ & 16 & $\begin{array}{l}\text { CDAI decreased by } 167 \text { points at } \\
\text { day } 42 \\
53 \% \text { remission at week } 42 \\
47 \% \text { endoscopic improvement }\end{array}$ \\
\hline Mayer et $\mathrm{a}^{25}$ & 2013 & alloP-MSC & Luminal & $\begin{array}{l}\text { Prospective } \\
\text { Phase I }\end{array}$ & 12 (CD only) & $\begin{array}{l}\text { Day } 29 \text { I00\% low dose, and 50\% } \\
\text { high dose with clinical response } \\
\text { Day } 29 \text { low dosing with } 50 \% \\
\text { remission and continued day } 365\end{array}$ \\
\hline $\begin{array}{l}\text { Melmed } \\
\text { et } \mathrm{al}^{26}\end{array}$ & 2015 & alloP-MSC & Luminal & $\begin{array}{l}\text { Prospective } \\
\text { Phase lb/lla } \\
\text { (follow-up to } \\
\text { Mayer et al) }\end{array}$ & 46 (CD only) & $\begin{array}{l}\text { At } 4 \text { and } 6 \text { weeks response seen: } \\
\text { Group I unit } 33.3 \%(P=0.042) \\
\text { Group } 4 \text { units } 38.5 \%(P=0.013) \\
\text { Placebo } 0 \\
\text { I } 4 \text { subjects experienced SAE }\end{array}$ \\
\hline Hu et $\mathrm{al}^{27}$ & 2016 & $\begin{array}{l}\text { alloUC- } \\
\text { MSC }\end{array}$ & Luminal & Phase I/II & 80 (UC only) & $\begin{array}{l}\text { Treatment group with alloUC- } \\
\text { MSC showed }>3 \text { decrease Mayo } \\
\text { score after } 3 \text { months compared } \\
\text { to placebo group ( } 85.3 \% \text { vs } 15.7 \% \text {, } \\
P=0.007)\end{array}$ \\
\hline Zhang et $\mathrm{a}^{28}$ & 2018 & $\begin{array}{l}\text { alloUC- } \\
\text { MSC }\end{array}$ & Luminal & $\begin{array}{l}\text { Prospective } \\
\text { open-label } \\
\text { clinical trial }\end{array}$ & 82 (CD only) & $\begin{array}{l}\text { I } 2 \text { months after alloUC-MSC } \\
\text { CDAI showed a decrease of } \\
23.6 \pm 12.4(P<0.0 \mathrm{I}) \\
\text { Requirements of steroid dosing } \\
\text { decrease after treatment by } \\
\mathrm{I} .2 \pm 0.35 \mathrm{mg} / \text { day }(P<0.05) \\
\text { No patients achieved complete } \\
\text { remission }\end{array}$ \\
\hline $\begin{array}{l}\text { Ditschkowski } \\
\text { et } \mathrm{a}^{29}\end{array}$ & 2003 & $\begin{array}{l}\text { Mixed } \\
\text { treatment }\end{array}$ & Luminal & Retrospective & 11 & $\begin{array}{l}90.9 \% \text { with no disease after } \\
\text { transplantation for } 34 \text { months }\end{array}$ \\
\hline
\end{tabular}

Abbreviations: alloP-MSC, allogeneic placenta-derived mesenchymal stem cells; alloUC-MSC, allo umbilical cord-derived MSC; BMT, bone marrow transplantation; CD, Crohn's disease; CDAI, Crohn's Disease Activity Index; CRPs, C-reactive proteins; HSCT, hematopoietic-derived stem cell therapy; IBD, inflammatory bowel disease; MSC, mesenchymal stem cells; SAE, serious adverse event; UC, ulcerative colitis.

removed due to infusion error. Thus, a total of 24 patients with severe active Crohn's colitis were given autoHSCT. The study protocol had autoHSCT with CTX and G-CSF given to patients to achieve CD34+ cell count of $2.0 \times 10^{6} / \mathrm{kg}$. During this trial, patients were treated with supportive care utilizing ciprofloxacin, fluconazole, metronidazole, acyclovir, and if needed piperacillin/tazobactam for neutropenia. CDAI and CSI were evaluated before, and 6 and 12 months after, and yearly for 5 years after transplantation. CDAI and CSI both had significant post-autoHSCT improvement to CDAI $<150$ and CSI $<12$ with $P<0.06$ at 5 years, with rates of remission achieved between $70 \%$ and $80 \%$ at 5 years. Clinical remission, which the authors defined as patients not having to initiate medical treatment again for CD, was $91 \%$ after year
1 and $19 \%$ at year $5 .{ }^{10}$ Unfortunately, 12 patients required surgery after autoHSCT.

Similar results were reported by Hommes et al in 2011. ${ }^{11}$ Three patients were recruited and underwent completed stem cell mobilization. However, conditioning and autoHSCT with CD34+ cell selection was performed in only two patients. These patients had no relapse of disease 5-6 years post transplantation. The third patient who only had mobilization did experience relapse 2 years after mobilization.

Hasselblatt et al evaluated the efficacy of high-dose chemotherapy with cyclophosphamide followed by autologous peripheral blood stem cell transplantation (autoPBSCT) in a series of 12 patients with severe refractory $\mathrm{CD} .{ }^{12} \mathrm{HSCT}$ with autoPBSCT harvest using high-dose cyclophosphamide was 
successfully performed in the majority of patients. As with other autoHSCT trials, supportive antibiotic care was provided. Patients were followed at 1, 3, 6, and 12 months after transplant with remission defined as $\mathrm{CDAI}<150$ and response defined as decrease of CDAI $<70$. Eleven of 12 patients had success in cell mobilization for transplant, with 7 of these having clinical and endoscopic improvement. There were five patients after 6 months who achieved complete remission. ${ }^{12}$

In 2012, Snowden's team published results on the safety of autoHSCT and survival in the posttransplant period. ${ }^{13}$ Six patients from three United Kingdom tertiary centers were included in the study. No treatment-related mortality was reported at 50-123 months post HSCT. ${ }^{14}$

Jauregui-Amezaga et al studied feasibility and toxicity of autoHSCT for the treatment of refractory luminal CD. Twenty-six patients were enrolled in this prospective study. Febrile neutropenia was observed in $62 \%$ and $95 \%$ of the patients during mobilization and conditioning phase, respectively. ${ }^{15}$ Similar results were reported in another prospective cohort study by Lopez-Garcia's team in $2016 .{ }^{14}$ Over a span of 8 years, 35 patients (initially there were 37 but bone marrow aspirate showed myelodysplastic syndrome in one patient and another patient received syngeneic HSCT from twin sister) with $\mathrm{CD}$ underwent a prospective single-center study evaluating safety and efficacy of autoHSCT for their refractory disease. Only 29 patients underwent autoHSCT and of these 29 patients about half had to remain and continue on prednisone during the trial. Thus, indicating continued refractory disease due to the continued need of steroids. ${ }^{14}$ Patients had a wide variety of disease locations including ileal, colonic, ileocolonic, ileal and upper gastrointestinal, and ileocolonic and upper gastrointestinal. The study assessed lab testing and CDAI at 30 days, every 6 weeks for 2 years, and then every 6 months for 5 years. Patients also underwent imaging by magnetic resonance imaging (MRI) at week 26 post transplant, and years 1,2, and 4. Definitions of clinical response were similar to prior studies in this review including a decrease CDAI $>100$ and clinical remission CDAI $<150$. Clinical remission was observed in the following: $70 \%$ at 6 months, $73 \%$ at 12 months, $93 \%$ at 3 years, $70 \%$ at 4 years, and $100 \%$ at 5 years. ${ }^{14}$ There were $65 \%$ of patients ( 13 of 20 ) who had endoscopic mucosal surveillance at 1 year with evidence of mucosal healing. Perianal disease did not improve, with only $16 \%$ of patients achieving remission with therapy. Peripheral arthropathy disappeared in $90 \%$ of patients.

One of the more impressive autoHSCT trials is the Autologous Stem Cell Transplantation International Crohn's Disease trials. ${ }^{15}$ This is the only randomized control trial to date on the efficacy of autoHSCT for CD. Forty-seven patients with refractory $C D$ underwent cell mobilization with 48 patients proceeding. This trial compared patients treated with mobilization vs transplantation of autoHSC 1 year later. Here, it was found that after autoHSCT, CDAI decreased from 324 to 161 points, 6 patients had normalization of CDAI, and CSI decreased from a median of 18 to $5 .^{15}$ This was in comparison to cell mobilization solely, in which CDAI went from 351 to 272 points, 1 patient had normalization of CDAI, and CSI went from 14 to 9 . Three of the patients achieved complete clinical and endoscopic remission with no drug requirements a year out after transplant. Unfortunately, there were many serious adverse events (SAE), the most common being infection.

This same research group went on to publish their further findings in 2017 using traditional end points for clinical CD trials. ${ }^{16}$ Three-months steroid-free clinical remission was seen in 13 patients after 1 year of HSCT. Half of the patients had complete endoscopic remission. Short disease duration and low baseline CDAI were associated favorably with the primary end points on multivariate analyses.

Rabian et al in 2016 conducted a retrospective review on adult patients with either UC or CD who underwent alloHSCT between January 2004 and December 2015 for hematological malignancy including acute leukemia, myelodysplastic syndrome/myeloproliferative neoplasms, non-Hodgkin's lymphoma, and multiple myeloma. ${ }^{17}$ Of the 18 identified patients ( 13 with CD and 5 with UC), 50 controls were matched for sex, age, transplantation, disease location, and intensity of conditioning. Outcomes evaluated incidence of graft-versus-host disease (GVHD) and nonrelapse mortality (NRM), and overall survival. About half of the patients had an identical sibling as a donor and the other a matched unrelated donor. GVHD developed in 7 patients with IBD and in 20 patients who were controls, resulting in an incidence of $39 \%$ in IBD patients at a median of 33 months and an incidence of $40 \%$ in controls at a median of 57 months. ${ }^{17}$ The authors concluded that IBD does not increase the risk of GVHD after alloHSCT. Overall, 7 patients with IBD and 19 patients in the control group died. NRM was $19 \%$ in the IBD group and $11 \%(P=0.89)$ in the control group. ${ }^{17}$ The overall conclusion of the study was that patients with IBD with hematological malignancies who underwent alloHSCT were no higher risk for GVHD or NRM.

\section{Autologous bone marrow-derived stem cell therapy trials}

Autologous bone marrow-derived mesenchymal stem cells (autoBM-MSC) are found to be an effective, feasible, and safe treatment option for refractory luminal CD. So far, small- 
scale Phase I clinical studies have been published. The first human trial to evaluate the effectiveness of intravenous (IV) MSC in severe and refractory CD was published by Onken. ${ }^{20}$ Ten patients were included in the study and randomized to receive either IV infusion of low-dose ( 2 million cells $/ \mathrm{kg}$ ) or high-dose ( 8 million cells $/ \mathrm{kg}$ ) human BM-MSC. The majority of the patients achieved improvement in their CDAI score. The primary end point ( $\geq 100$-point reduction in CDAI) was achieved by two patients within a week after treatment administration. IBD quotient scores increased to $\geq 170$ in $38 \%$ by day 28 . High doses of MSC infusion were found to be associated with greater reduction in CDAI scores, though this difference was not statistically significant.

Another Phase I clinical trial of 10 adults was conducted by Duijvestein et al in $2010 .{ }^{21}$ All patients included in this trial had refractory disease to standard treatment options including steroids, methotrexate, azathioprine, 6-mercaptopurine, and/ or anti-tumor necrosis factor (TNF) therapy such as infliximab. Patients had a baseline CDAI score of 326. Of the 10 patients initially included, one was excluded due to no active disease on initial colonoscopy. Nine patients received two IV doses of autoMSC $1-2 \times 10^{6}$ cells $/ \mathrm{kg}$ body weight 7 days apart. At weeks 0 and 6 , colonoscopies were performed to report endoscopic remission and patients had clinical assessment at weeks $0,1,2,4,6$, and 14. Patients were followed to monitor side effects of the treatment and reduction in CDAI scores. Besides minor allergic reactions, no major side effects were reported. Mean CDAI scores decreased $\geq 70$ from baseline to 6 weeks post treatment in five patients. However, complete clinical remission as defined by CDAI score $<150$ was not achieved in any patient. Two patients showed a decrease in Crohn's Disease Endoscopic Index Score of 10.0 and 24.7 points. No significant endoscopic improvement was seen between baseline and 6 weeks post infusion in five patients and no change in C-reactive protein was observed. ${ }^{21}$

Dhere et al performed a Phase I trial with 12 patients in both pediatric and adult gastroenterology clinics, with all subjects $>18$ years of age, utilizing autoBM-MSC. The study analyzed the safety and tolerability of autoMSC in medically refractory $\mathrm{CD} .{ }^{22}$ Subjects were stratified into different groups: four were administered 2 million cells $/ \mathrm{kg}$ bone weight (low dose) MSC IV, four were administered 5 million cells $/ \mathrm{kg}$ bone weight (intermediate dose) MSC IV, four were administered 10 million cells $/ \mathrm{kg}$ bone weight (high dose) MSC IV, and there were four control individuals as well. Unfortunately, 1 of the 12 subjects did not complete the study due to followup. MSC infusion was tolerated well in all patients and no dose-limiting toxicity was reported. There were seven patients with SAE, which included appendicitis, Clostridium difficile infection, and worsening refractory CD symptoms. As per previous studies, CDAI and CRP were monitored during the study pre and post infusions. Patients achieved improved CDAI but had worsening CRP values. The authors of this study concluded that it was safe. Yet, it is uncertain why this was determined given the documented results. ${ }^{22}$

\section{Allogeneic bone marrow-derived stem cell therapy trials}

In a Phase II pilot clinical study by Liang et al, 9 individuals with $\mathrm{CD}$ were treated with allogeneic bone marrow MSC (alloBM-MSC) transplantation. ${ }^{23}$ The study protocol had patients receiving an IV injection of $2 \times 10^{6}$ or $8 \times 10^{6}$ bone marrow MSC $/ \mathrm{kg}$. There was a significant reduction in CDAI in all patients 28 days post transplantation. Clinical remission (reduction in CDAI $\geq 100$ ) was observed in 3 of the 9 subjects. Mild adverse events were reported in five of these

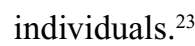

Forbes et al investigated the efficacy of alloBM-MSC in patients with luminal CD in a Phase II multicenter clinical trial. ${ }^{24}$ The researchers evaluated 16 subjects ( 13 with colitis, 2 with ileocolitis, 1 with ileitis) with CDAI $>250$ who previously failed biologic therapy. The study administered $2 \times 10^{6}$ $\mathrm{MSC} / \mathrm{kg}$ body weight infusions weekly for 4 weeks. The primary end point was CDAI reduction of $>100$ at day 42 . Other outcomes such as endoscopic improvement, quality of life, and clinical remission with CDAI $<150$ were also reported. Patients were off biologic therapy for 4 weeks or more, on prednisolone $10 \mathrm{mg}$ or less and/or immunomodulators such as 6-mercaptopurine, methotrexate, or azathioprine. Fourteen patients used steroids or immunomodulators during this study. Interestingly, five patients had previously underwent prior perianal abscess drainage with seton insertion, two with ileocolonic resections, and one with subtotal colectomy. The results of the study showed CDAI decreased 167 points at day $42(P<0.0001)$. A total of $53 \%$ of the subjects ( 8 of 15$)$ had clinical remission (CDAI $<150)$ at day 42 and endoscopic improvement occurred in $47 \%$ (7 of 15 ) of patients. There was only one SAE, which was a sigmoid adenocarcinoma. ${ }^{24}$

\section{Allogeneic placenta-derived stem cell treatment trials}

In the 2013 Phase I study, Mayer et al gave 12 patients with moderate to severe CD (CDAI scores 220-400) cenplace-L, MSC from full-term human placenta, either high dosing $\left(8 \times 10^{8}\right.$ cells $)$ or low dosing $\left(2 \times 10^{8}\right.$ cells $)$. Patients were split into two groups of six individuals each and were administered 
allogeneic placenta-derived mesenchymal stem cells (alloPMSC) at day 0 and day 7 via IV catheter. ${ }^{25}$ Only one patient did not receive both infusions. By day 29 , all six patients in the low-dose group and three patients $(50 \%)$ in the high-dose group had a clinical response (CDAI decrease of 70 points from baseline). Low dosing appeared to have better response with $50 \%$ remission (defined as a CDAI $<150$ and a decrease of 100 from baseline) at day 29 and continued 1 year out. Only one patient had remission at day 180 in the high-dose group, which did not continue 1 year out. Treatment adverse events were headache and hematuria. Other adverse events included worsening IBD, infections such as urinary tract infection, and breast cancer.

In 2015, a follow-up Phase Ib/IIa study using PDA-001 (cenplace-L) followed up on its prior 2013 study by Mayer et al. ${ }^{26}$ The Phase Ib study had four subjects given 8 units $(1.2 \times$ $10^{9}$ cells) of alloP-MSC at days 0 and 7. Phase IIa had 46 individuals with moderate to severe CD (CDAI 220-450) randomly assigned into three groups: 16 received placebo, 15 received 1 unit $\left(1.5 \times 10^{8}\right.$ cells $)$ and 15 received 4 units $\left(6 \times 10^{8}\right.$ cells $)$ that underwent infusions on day 0 and day 7 . All patients received pretreatment prior to administration with hydrocortisone 50 $\mathrm{mg}$ IV, diphenhydramine $50 \mathrm{mg}$ IV, and hydrocortisone 100 mg orally the previous night. Two patients in the 4 unit group did not complete the study due to withdrawing consent, and missing key data. The response of patients who had CDAI improvement of 100 points or $25 \%$ from baseline at weeks 4 and 6 were as follows: $33.3 \%(P=0.042)$ in the group with 1 unit, $38.5 \%(P=0.013)$ in the group with 4 units, and $0 \%$ in placebo group. Remission was seen in $13.3 \%$ patients in the group with 1 unit, $15.4 \%$ in the group with 4 units and $0 \%$ in placebo group. ${ }^{26}$ Non-SAE were seen and included headache, chest pain, migraine, infusion site pain, edema, thrombophlebitis, phlebitis, venous thrombosis, pruritus, erythema, arthralgia, joint swelling, flushing, palpitations, throat irritation, and others despite pretreatment of infusion. Infections such as urinary tract infections, pneumonia, sinusitis, and vulvovaginal mycotic infection occurred in $6 \%-8 \%$ of patients. Overall, 14 patients had SAE which included perforated gastric ulcer, anal cancer, hypersensitivity reactions, colon cancer, and worsening IBD. The authors concluded that primary end points of response at weeks 4 and 6 were obtained. However, there were numerous side effects as listed above.

\section{Allogeneic umbilical cord stem cell treatment}

In 2016, Hu et al published a Phase I/II randomized controlled study with 80 patients with UC (baseline Mayo score 8-10) with group 1 receiving allogeneic umbilical cord-derived mesenchymal stem cells (alloUC-MSC) and group 2 receiving placebo - both groups were allowed to continue base treatments. ${ }^{27}$ Patients with alloUC-MSC were given IV on days 0 and 7. Ten patients withdrew from the study due to unable to tolerate colonoscopy or time-related issues. Treatment group with alloUC-MSC showed a >3 decrease in Mayo score after 3 months compared with the placebo group ( $85.3 \%$ vs $15.7 \% ; P=0.007)$. This score was sustained in the treatment group 6 months out as well. No AE or SAE occurred during this trial.

Zhang et al in 2018 published their prospective, randomized, open-label clinical trial from 2012 to 2015 on umbilical cord MSC in patients with moderate to severe CD (CDAI $220-450) .{ }^{28}$ The study selected 82 patients totally and divided this group into two, where half received four peripheral IV infusions of $1 \times 10^{6}$ alloUC-MSC weekly and the other half received placebo; all participants were then followed for 12 months. Only one patient in the treatment group did not complete follow-up analysis. CDAI 12 months after alloUCMSC showed a decrease of 23.6 \pm 12.4 in the treatment group $(P<0.01)$. Requirements of steroid dosing were also seen to decrease after treatment by $1.2 \pm 0.35 \mathrm{mg} /$ day $(P<0.05) .{ }^{28} \mathrm{No}$ patients in this study achieved complete remission defined by a $\mathrm{CDAI}<150$. Anal fistula was seen to improve in patients in the alloUC-MSC group and not in the control group. Adverse events included fever after infusion and upper respiratory infections. There were no SAE.

\section{Mixed stem cell treatment modalities}

One of the initial stem cell therapy studies published in 2003 by Ditschkowski et al evaluated 11 patients who had either chronic myeloid leukemia or myelodysplastic syndrome with IBD and underwent allogeneic stem cell therapy. ${ }^{29}$ These patients received either chemotherapy alone vs total body radiation with cyclophosphamide plus antithymocyte globulin or thiotepa. This study included a mix of BMT vs hematopoietic derived transplant with seven patients having $\mathrm{CD}$ and four having UC. Some bias was observed as five patients did not have any activity at transplantation and six patients had low disease activity at transplantation. Ten of the eleven subjects did not have disease activity after transplantation, with only one patient showing continued disease. ${ }^{29}$ Patients were followed for up to 34 months after transplantation. Only one patient experienced significant adverse events, which included pulmonary fungal infection leading to death. The most interesting outcome of the study showed that two patients who suffered from dermatological 
and rheumatological complaints such as arthropathy and psoriasis had resolution of their symptoms after transplantation.

\section{Stem cell therapy for fistulizing disease}

Fistulizing disease is very common in IBD, with approximately $25 \%$ of $\mathrm{CD}$ patients developing fistulas within 20 years of their disease diagnosis. ${ }^{30}$ Unfortunately, many patients do not respond over the long term to medical therapy, with approximately $10 \%-33 \%$ not responding to antibiotics or anti-TNF medications, a $90 \%$ recurrence following antibiotic treatment and $50 \%$ recurrence following infliximab. ${ }^{31,32}$ Thus, there is a great need for other therapies to treat fistulas in IBD.

Four groups of stem cell therapies have been studied for fistulizing IBD, including embryonic, tissue-specific, mesenchymal, and induced pluripotent stem cells. Most of these studies used MSC therapy, both autologous and allogeneic. Certain criteria for MSC in vitro must be met per the International Society for Cellular Therapy, which include differentiation potential ie, adipogenic lineages, expression of surface antigens including HLA DR-, CD79a, CD19-, CD14-, CD11b-, CD45-, CD34-, CD105+, CD90+, CD73+, and the ability to adhere to plastic. ${ }^{33}$ The following studies largely held the same exclusion criteria unless otherwise specified. These included evidence of infection, need for antibiotics or immediate surgery, patient preference to not use contraceptives, pregnancy or breast-feeding, complex fistulas with more than two openings or malignancy within the past 5 years, and any evidence of end-organ failure. Fistulas in the studies were largely transsphincteric, suprasphincteric, and extrasphincteric and sometimes rectovaginal. An overview of these detailed studies is described in Table 2 .

\section{Autologous adipose tissue-derived stem cell therapy trials}

Autologous adipose tissue-derived stem cells (autoASC) were examined by Cho et al in a Phase I nonrandomized, open-label dose escalation trial involving 10 subjects. . $^{34,35}$ Equal representation of both sexes were present, and patients had transsphincteric, suprasphincteric, and extrasphincteric fistulas. Three patients were given $1 \times 10^{7}$ cells $/ \mathrm{mL}$ (group 1), four patients were given $2 \times 10^{7}$ cells $/ \mathrm{mL}$ (group 2), and then the third group was given $4 \times 10^{7}$ cells $/ \mathrm{mL}$ (group 3); regarding dosage, " $3 \times 10^{7}$ cells per centimeter of length were injected when the diameter of the fistula was not above $1 \mathrm{~cm}$, and twice that number of cells was administered when the diameter of the fistula was $1 \mathrm{~cm}<\mathrm{d} \leq 2 \mathrm{~cm}$ ". ${ }^{35}$ Patients had physical examinations, blood samples, and laboratory tests at 2, 4, 6, and 8 months. Unfortunately, one patient dropped out due to an insufficient number of autoASC. No adverse events from the autoASC were seen. Partial closure was seen in three patients in group 1, complete closure in two patients in group 2, and in group 3 one with complete healing and one with partial closure. Of the three patients with complete closure, these remained closed at 6 months follow-up with no adverse safety events occurring. ${ }^{35}$

A group led by Lee et al also performed a follow-up Phase II study which was a multicenter dose-proportional clinical trial that included patients with perianal $\mathrm{CD}$ with fistulas $<2$ $\mathrm{cm}$ in length. ${ }^{36}$ Thirty-three patients underwent local injection of either $3 \times 10^{7}$ of $6 \times 10^{7}$ cells per centimeter length with an average of $15.8 \times 10^{7}$ autoASC followed by a second injection of the $1.5 \times$ the prior dose with an average of $19.1 \times 10^{7}$ if incomplete closure was observed at week 8 . Patients were evaluated at 4, 6, and 8 weeks after injection with photography, and if no complete healing was found at week 8 , the subjects were reinjected with autoASC. Complete healing was defined as "complete closure of fistula tract and internal and external openings, without drainage or any sign of inflammation". ${ }^{36}$ Amazingly, $79 \%$ of patients achieved complete closure after one dose, and $88.5 \%$ of patients did not have disease recurrence at 12 months. A total of $82 \%$ (27 of 33) of patients had fistula healing at the 8 -week analysis with $88 \%$ (23 of 26 ) of patients continuing to have fistula resolution at 12 months. ${ }^{36}$ Of the 6 patients who had incomplete closure, 5 had $50 \%$ healing with decreased drainage. No SAE were seen. One of the limits of this trial was the large variety of subjects' disease, particularly the duration of fistulas present.

Moreover, Cho et al continued analysis regarding 41 of 43 patients in their previous Phase II trial with dosage proportional autoASC administration for another 1 year in a retrospective chart review. ${ }^{34}$ The authors investigated sustainability, safety, and efficacy of autoASC 2 years after original ASC administration. Three subjects were excluded from this analysis due to undergoing procedures during this timeframe; four were excluded due to lack of data. The authors found that $82 \%$ of individuals achieved complete resolution of fistulas, and durability was $80 \%(P \leq 0.0001)$ at 1 year and $75 \%(P \leq 0.001)$ at 2 years. ${ }^{34}$

Lastly, Dietz et al performed a Phase I, single-center, nonrandomized trial evaluating stem cell treatment for patients with refractory perianal fistulizing disease on biologic therapy with infliximab, adalimumab, and certolizumab. Twelve patients were given a stem cell-loaded plug which consisted of Stem Cells on Matrix Plugs derived from concentrated 
Table 2 Overview of stem cell studies for treatment with patients having fistulizing disease

\begin{tabular}{|c|c|c|c|c|c|c|}
\hline Author & Date & $\begin{array}{l}\text { Stem cell } \\
\text { type }\end{array}$ & $\begin{array}{l}\text { Treatment } \\
\text { location }\end{array}$ & Study type & Patients (n) & Results \\
\hline Cho et $\mathrm{al}^{35}$ & 2013 & $\begin{array}{l}\text { Autologous } \\
\text { adipose } \\
\text { tissue }\end{array}$ & Fistulizing & $\begin{array}{l}\text { Prospective } \\
\text { Phase I }\end{array}$ & $\begin{array}{l}9 \text { (I excluded } \\
\text { due to insufficient } \\
\text { number of ASCs) }\end{array}$ & $\begin{array}{l}77.8 \% \text { patients with } \\
\text { healing of fistulas ( } 33.3 \% \\
\text { with complete remission) } \\
33.3 \% \text { with remission } \\
\text { remained in remission at } \\
6 \text { months }\end{array}$ \\
\hline Lee et $\mathrm{al}^{36}$ & 2013 & $\begin{array}{l}\text { Autologous } \\
\text { adipose } \\
\text { tissue }\end{array}$ & Fistulizing & $\begin{array}{l}\text { Prospective } \\
\text { Phase II }\end{array}$ & 33 & $\begin{array}{l}79 \% \text { resolution fistula } \\
\text { after one dose and } 88.5 \% \\
\text { durability at } 12 \text { months } \\
83.3 \% \text { patients with } \\
\text { incomplete closure of } \\
\text { fistula had } 50 \% \text { healing } \\
\text { with decreased drainage }\end{array}$ \\
\hline Cho et $\mathrm{al}^{34}$ & 2015 & $\begin{array}{l}\text { Autologous } \\
\text { adipose } \\
\text { tissue }\end{array}$ & Fistulizing & $\begin{array}{l}\text { Prospective } \\
\text { Phase II }\end{array}$ & $\begin{array}{l}44 \text { ( I initially } \\
\text { with } 3 \text { excluded } \\
\text { due to ongoing } \\
\text { procedures and } 4 \\
\text { excluded due to } \\
\text { data) }\end{array}$ & $\begin{array}{l}82 \% \text { resolution of fistulas } \\
80 \% \text { durability at I year } \\
\text { and } 75 \% \text { at } 2 \text { years }\end{array}$ \\
\hline Dietz et $\mathrm{a}^{37}$ & 2017 & $\begin{array}{l}\text { Autologous } \\
\text { adipose } \\
\text { tissue }\end{array}$ & Fistulizing & $\begin{array}{l}\text { Prospective } \\
\text { Phase I }\end{array}$ & 12 & $\begin{array}{l}75 \% \text { resolution of fistulas } \\
\text { at } 3 \text { months } \\
83.3 \% \text { resolution of } \\
\text { fistulas at } 6 \text { months }\end{array}$ \\
\hline $\begin{array}{l}\text { Ciccocioppo } \\
\text { et } \mathrm{a}^{38,39}\end{array}$ & $\begin{array}{l}2011, \\
2015\end{array}$ & $\begin{array}{l}\text { Autologous } \\
\text { BMT }\end{array}$ & Fistulizing & $\begin{array}{l}\text { Prospective } \\
\text { Phase II }\end{array}$ & $\begin{array}{l}7 \text { (I0 with } 2 \\
\text { patients excluded } \\
\text { due to not wanting } \\
\text { treatment, I } \\
\text { moved) }\end{array}$ & $\begin{array}{l}70 \% \text { resolution of fistulas, } \\
30 \% \text { improvement of } \\
\text { fistulas } \\
\text { All patients with } \\
\text { reduction of CDAI } \\
88 \% \text { resolution of fistula } \\
\text { at I year } \\
50 \% \text { resolution of fistula } \\
\text { at } 2 \text { years } \\
37 \% \text { resolution of fistula } \\
\text { at } 5 \text { years }\end{array}$ \\
\hline $\begin{array}{l}\text { Garcia- } \\
\text { Arranz } \\
\text { et a }\left.\right|^{40}\end{array}$ & 2016 & $\begin{array}{l}\text { Allogeneic } \\
\text { adipose } \\
\text { tissue }\end{array}$ & Fistulizing & $\begin{array}{l}\text { Phase I/II } \\
\text { prospective }\end{array}$ & 10 & $\begin{array}{l}90 \% \text { resolution of fistula } \\
60 \% \text { sustained fistula } \\
\text { healing at I year }\end{array}$ \\
\hline $\begin{array}{l}\text { de La } \\
\text { Portilla } \\
\text { et al }{ }^{41}\end{array}$ & 2013 & $\begin{array}{l}\text { Allogeneic } \\
\text { adipose } \\
\text { tissue }\end{array}$ & Fistulizing & $\begin{array}{l}\text { Phase I/II } \\
\text { prospective }\end{array}$ & 24 & $\begin{array}{l}69.2 \% \text { reduction of fistula } \\
38.1 \% \text { resolution of } \\
\text { fistula at week } 12 \\
65.3 \% \text { resolution of } \\
\text { fistula at week } 24\end{array}$ \\
\hline $\begin{array}{l}\text { Panés } \\
\text { et al }\left.\right|^{43,44}\end{array}$ & $\begin{array}{l}2016, \\
2018\end{array}$ & $\begin{array}{l}\text { Allogeneic } \\
\text { adipose } \\
\text { tissue }\end{array}$ & Fistulizing & $\begin{array}{l}\text { Phase III } \\
\text { randomized } \\
\text { double-blind }\end{array}$ & $\begin{array}{l}88 \text { treatment arm } \\
\text { and } 83 \text { placebo } \\
\text { (initially } 212 \text { prior } \\
\text { to exclusions) }\end{array}$ & $\begin{array}{l}50 \% \text { fistula resolution vs } \\
34 \% \text { placebo } \\
59.2 \% \text { fistula resolution } \\
\text { vs } 41.6 \% \text { placebo } \\
56.3 \% \text { combined } \\
\text { remission }\end{array}$ \\
\hline Park et al ${ }^{42}$ & 2016 & $\begin{array}{l}\text { Allogeneic } \\
\text { adipose } \\
\text { tissue }\end{array}$ & $\begin{array}{l}\text { Perianal/ } \\
\text { fistulizing }\end{array}$ & $\begin{array}{l}\text { Prospective } \\
\text { pilot study }\end{array}$ & 6 & $\begin{array}{l}\text { Complete healing in } \\
16.7 \% \text { patients at } 8 \\
\text { weeks and } 50 \% \text { at } 8 \\
\text { months. } \\
\text { No related adverse } \\
\text { events. }\end{array}$ \\
\hline
\end{tabular}


Table 2 (Continued)

\begin{tabular}{|c|c|c|c|c|c|c|}
\hline Author & Date & $\begin{array}{l}\text { Stem cell } \\
\text { type }\end{array}$ & $\begin{array}{l}\text { Treatment } \\
\text { location }\end{array}$ & Study type & Patients (n) & Results \\
\hline $\begin{array}{l}\text { Wainstein } \\
\text { et } \mathrm{al}^{45}\end{array}$ & 2018 & $\begin{array}{l}\text { Allogeneic } \\
\text { adipose } \\
\text { tissue }\end{array}$ & Fistulizing & $\begin{array}{l}\text { Prospective } \\
\text { observational }\end{array}$ & 9 & $\begin{array}{l}90.9 \% \text { resolution of } \\
\text { fistulas } \\
9.1 \% \text { partial resolution } \\
\text { of fistula }\end{array}$ \\
\hline $\begin{array}{l}\text { Molendijk } \\
\text { et } \mathrm{al}^{30}\end{array}$ & 2015 & $\begin{array}{l}\text { Allogeneic } \\
\text { BMT }\end{array}$ & Fistulizing & $\begin{array}{l}\text { Randomized } \\
\text { double blind } \\
\text { placebo } \\
\text { controlled }\end{array}$ & 21 & $\begin{array}{l}\text { Three groups with dose } \\
\text { escalations showing } \\
\text { group I } 66.7 \% \text {, group } 2 \\
85.7 \% \text {, group } 328.6 \% \\
\text { fistula healing vs placebo } \\
33.3 \%\end{array}$ \\
\hline $\begin{array}{l}\text { Sanz-Baro } \\
\text { et } \mathrm{al}^{46}\end{array}$ & 2015 & $\begin{array}{l}\text { Mixed stem } \\
\text { cell }\end{array}$ & Fistulizing & Retrospective & 5 & $\begin{array}{l}80 \% \text { with } 18-24 \\
\text { months after ASC } \\
\text { administration were able } \\
\text { to have gestation and had } \\
\text { cesarean deliveries } \\
40 \% \text { after ASC reported } \\
\text { gestational complications }\end{array}$ \\
\hline $\begin{array}{l}\text { Garcia- } \\
\text { Olmo et } \mathrm{al}^{47}\end{array}$ & 2005 & $\begin{array}{l}\text { Autologous } \\
\text { adipose } \\
\text { tissue }\end{array}$ & Perianal & $\begin{array}{l}\text { Prospective } \\
\text { Phase I }\end{array}$ & 4 & $\begin{array}{l}75 \% \text { tissue repair } \\
\text { at week } 8 \text { with no } \\
\text { recurrence or adverse } \\
\text { events at } 2 \text { years }\end{array}$ \\
\hline $\begin{array}{l}\text { Garcia- } \\
\text { Olmo et } \mathrm{al}^{48}\end{array}$ & 2009 & $\begin{array}{l}\text { Autologous } \\
\text { adipose } \\
\text { tissue }\end{array}$ & $\begin{array}{l}\text { Perianal/ } \\
\text { fistulizing }\end{array}$ & $\begin{array}{l}\text { Prospective } \\
\text { Phase Ilb }\end{array}$ & $\begin{array}{l}\text { CD Fistulas I4 } \\
\text { Perianal } \\
\text { cryptoglandular } 35\end{array}$ & $\begin{array}{l}\text { 7I\% combination therapy } \\
\text { of MSC plus fibrin glue vs } \\
16 \% \text { fibrin alone healing }\end{array}$ \\
\hline $\begin{array}{l}\text { Guadalajara } \\
\text { et } \mathrm{al}^{49}\end{array}$ & 2012 & $\begin{array}{l}\text { Autologous } \\
\text { adipose } \\
\text { tissue }\end{array}$ & $\begin{array}{l}\text { Perianal/ } \\
\text { fistulizing }\end{array}$ & $\begin{array}{l}\text { Prospective } \\
\text { Phase II }\end{array}$ & $\begin{array}{l}\text { CD } 8 \text { (5 } \\
\text { combination and } 3 \\
\text { solely glue) } \\
\text { Cryptoglandular I } 3\end{array}$ & $\begin{array}{l}\text { Complete healing } 57.1 \% \\
\text { combination treatment } \\
\text { and } 23 \% \text { solely glue }\end{array}$ \\
\hline
\end{tabular}

Abbreviations: ASCs, adipose tissue-derived stem cells; BMT, bone marrow transplantation; CD, Crohn's disease; CDAI, Crohn's Disease Activity Index; MSC, mesenchymal stem cells.

adipose-derived MSC attached to a bioabsorbable matrix (MSC-MATRIX), and complete clinical healing occurred in $75 \%$ ( 9 of 12 patients) at 3 months, and 83.3\% (10 of 12 patients) within 6 months. ${ }^{37} \mathrm{MRI}$ was utilized for analysis of the fistula tracts at baseline and 6 months later to confirm healing. No SAE were observed and thus the authors concluded that plug placement with autoASC therapy was safe and effective.

\section{Autologous bone marrow-derived stem cell therapy trials}

The data regarding autoBM-MSC for IBD fistulas are quite sparse. In 2007-2014, Ciccocioppo et al, in their Phase II clinical trial with patients who had active complex perianal $\mathrm{CD}$ with fistulas that were refractory to medical and surgical therapies, examined autoBM-MSC for safety and efficacy in fistulizing CD. ${ }^{38}$ Patients had been previously treated with biologic therapies including anti-TNF medications. Local injection into the fistulas of $1.5-3 \times 10^{7}$ autoBM-MSC every 3 months was performed until healing was achieved or until they were no longer available (two to five injections totally). All patients during this study underwent treatment with mesalamine and azathioprine except for two patients on mesalamine monotherapy and two patients treated with prednisone and mesalamine. Seventy percent ( 7 of 10) of patients achieved complete resolution of fistulas at 8 and 52 weeks with no SAE; 30\% (3 of 10) of patients who did not have complete resolution demonstrated slight improvement of their fistulas but had incomplete closure. ${ }^{39}$ The authors continued this work and found that after treatment with autoBM-MSC, subjects achieved fistula relapse-free survival of $88 \%, 50 \%$, and $37 \%$ at 1,2 , and 5 years later with no documented adverse events. ${ }^{38}$ Thus, autoBM-MSC was considered to be safe and efficacious for fistulizing CD.

\section{Allogeneic adipose tissue-derived stem cell therapy trials}

Many large studies have evaluated allogeneic ASC (alloASC) for fistulizing IBD. Garcia-Arranz et al led a Phase I/II 
nonrandomized, open-label trial studying alloASC as a treatment for Crohn's-related rectovaginal fistulas (CRRVF) in 10 subjects. ${ }^{40}$ The study's primary end point was safety and feasibility, and patients were followed at 1, 4, 8, 12, 24, and 52 weeks after alloASC administration. A second dose of alloASC was administered if complete healing of the fistula was not achieved at 12 weeks. CRRVF was defined as healed "when the vaginal and rectal walls showed complete re-epithelialization and absence of vaginal drainage, including feces, flatus or suppuration". ${ }^{40}$ Nine subjects achieved complete fistula healing during the study, yet fistula reoccurrence took place in seven of these patients. Due to subject exclusions including need for biologic therapy or surgeries, the final efficacy rate for sustained fistula healing at 52 weeks was $60 \%$ (three of five patients did not have recurrence). The study authors decided that the primary end point was met as the treatment was found to be safe and feasible.

de La Portilla et al evaluated alloASC for complex CD perianal fistulas in 24 subjects across a Phase I/II open-label, single-arm, nonrandomized multi-center study. ${ }^{41}$ The primary end point was safety and efficacy of alloASC in this disease population. The subjects underwent initial MRI followed by alloASC injection, with a second injection if incomplete closure was found at 12 weeks. The study concluded at 24 weeks, and the same definition of closure as the Lee et al study was used with evaluation at weeks 10, 12, 22, and 24 by both the treating physician and a blinded gastroenterologist/ surgeon. ${ }^{36,41}$ The authors found that $69.2 \%$ patients achieved reduction in their fistula size, with $38.1 \%$ patients achieving complete closure at week 12 and $65.3 \%$ at week $24 .{ }^{41}$ Thus, alloASC was determined to be safe and efficacious in the treatment of complex perianal CD fistulas.

A smaller study conducted by Park et $\mathrm{al}^{42}$ utilized alloASC in a prospective pilot study with dose escalation of two groups with three patients in each for a total of six patients. Group 1 was given $1 \times 10^{7}$ cells $/ \mathrm{mL}$ based on the length and diameter of the fistula tract, and group 2 was given a higher dose of $3 \times 10^{7}$ cells $/ \mathrm{mL}$. These patients were followed for an additional 6 months. Of note, one of the patients in group 2 withdrew from the study. There were no related adverse events. However, one patient did get a fistula in another site. AlloASC was safe and well tolerated during this study. The results were one patient in group 2 with complete healing at 8 weeks $(16.7 \%)$ and three patients (two in group 2 and one in group 1) with complete healing at 8 months (50\%).

Next, Panés et al completed a Phase III randomized, double-blind, parallel-group, placebo-controlled, multicenter study using alloASC for treatment in complex perianal
CD fistulas, dubbed the ADMIRE-CD trial. ${ }^{43}$ Patients with stenosis, CRRVF, diverting stoma, or abscesses $>2 \mathrm{~cm}$ were excluded in addition to the above criteria. Inclusion criteria for the study were patients with refractory disease to immunosuppressives, antibiotics, or biologics such as anti-TNF drugs. Closure was defined similar to the aforementioned studies. A total of 212 subjects were originally included, and at completion of the 24 weeks, 88 subjects were in the treatment arm and 83 in the placebo arm. Overall, 50\% of patients treated with alloASC either individually or in combination with medical treatment achieved remission, compared with $34 \%$ in the placebo group $(P=0.024) .{ }^{43}$ Treatment was found to be safe and effective with similar adverse reactions occurring more in the placebo group, likely from the disease course in CD.

Panés et al also published study results this year regarding an extension of the ADMIRE-CD trial from 24 weeks to 52 weeks, documenting both clinical remission and combined remission. They defined these remissions as "clinical assessment of closure of all treated external openings that were draining at baseline, and the absence of collections $>2 \mathrm{~cm}$ ". ${ }^{44}$ This Phase III randomized clinical trial utilized alloASC and was a multisite study with 212 patients included across 49 hospitals in Europe and Israel who had refractory complex perianal CD with fistulas. Patients were required to have a maximum of two internal and/or three external openings, which were draining for at least 6 weeks to be included in the study. This extended study found that alloASC is superior to placebo with clinical remission in $59.2 \%$ of subjects treated with Cx601 vs $41.6 \%$ of subjects given placebo $(P=0.013)$, and combined remission achieved in $56.3 \%$ treated subjects vs $38.6 \%$ subjects given placebo $(P=0.010) .{ }^{44}$ Twenty-four weeks after one local injection, those given alloASC had significant improvement delineated by closure of external fistulous tract and no fluid collections $>2 \mathrm{~cm}$ on MRI. The authors found 53 of 107 subjects (50\%) treated with alloASC healed as opposed to placebo (34\%). Remission was seen quicker with alloASC with 6.7 weeks compared with placebo with 14.6 weeks. It should be noted that all patients were given alloASC or placebo underwent fistula curettage, internal orifice closure, and surgical drainage. Further expansion studies stemming from this one are on the horizon.

Finally, Wainstein et al published a single-center prospective observational pilot study conducted during 2013-2016 including nine patients. ${ }^{45}$ Two stages were included in this trial which were 1) "examination under anesthesia, fistula mapping, drainage and seton placement" and 2) setons removed 4-6 weeks with subsequent debridement and ASC 
then injected with biological plug formation. Three classes of treatment results were described: complete healing, partial healing, and no healing. Partial healing was defined as external fistula opening remaining but with a decrease of $>50 \%$ in size. This trial found complete healing in 10/11 patients' fistulas and $1 / 11$ partial healing. ${ }^{45}$ The authors decided that excellent success rates can be made for fistulizing CD with a therapy method including alloASC, platelet-rich plasma, and endorectal advancement flaps.

\section{Allogeneic bone marrow-derived stem cell therapy trials}

Regarding alloBM-MSC for IBD fistulas, the data are largely limited to one study. Molendijk et al performed a randomized, double-blind, placebo-controlled, dose-escalating study utilizing alloBM-MSC along with surgical treatment for 21 patients with refractory perianal fistulizing CD. ${ }^{30}$ Five patients were given a single shot of $1 \times 10^{7}$ alloBM-MSC, five were given $3 \times 10^{7}$ alloBM-MSC, five were given $9 \times 10^{7}$ alloBMMSC, and six were given placebo. AlloBM-MSC were injected around the internal openings of the fistula walls. The study used either alloBM-MSC from five different donors or normal saline-5\% albumin solution as placebo, along with surgery performed by two surgeons with expertise in IBD. Fistula healing was evaluated by photography at weeks 0,12 , and 24 , in addition to finger pressure at external openings and MRI at week 12 . The primary end points were absence of discharge and absence of collections of $>2 \mathrm{~cm}$ on MRI. The results showed $66.7 \%, 85.7 \%$, and $28.6 \%$ fistula healing for the three groups at week 24 compared with $33.3 \%$ healing in the placebo group ( $P=0.06$ group 2 vs placebo).$^{30}$ Promising results were seen at week 12 (study's primary end point) and continued through week 24 . The most beneficial dose of alloBM-MSC was seen in the $3 \times 10^{7}$ alloBM-MSC group. The authors determined that alloBM-MSC are superior to placebo for fistula healing for those with refractory perianal fistulizing CD.

\section{Mixed stem cell treatment modalities}

Notably, a case study published in 2015 demonstrated the reproductive outcomes of five pregnant females with fistulizing CD treated with ASC. ${ }^{46}$ Three of the subjects had CRRVF and two had perianal fistulas and had undergone ASC injection with resolution of their fistulas and subsequent ability for pregnancy (between 17-48 months). Thus, three patients received autoASC and two patients had received alloASC prior to conception, with all five patients in their 30s during administration of ASC, and all five patients in their mid-30s to early 40 s of age at gestation. ${ }^{46}$ All but one patient had a period of 18-24 months between ASC administration and gestation. Following their pregnancies, the patients were given data collection sheets. Two of the five patients reported gestational complications, namely being first trimester miscarriages (no treatment during pregnancy) and fetal growth restriction and small for gestational age (azathioprine during pregnancy). Of the patients who gave birth, all four patients underwent cesarean section with one newborn malformation occurring, which was syndactyly with clinodactyly. ${ }^{46}$

\section{Stem cell therapy for perianal disease}

Perianal disease in IBD is seen in patients with CD. Around one-third of patients with $\mathrm{CD}$ will have perianal disease, which is disease and inflammation around the anus. Commonly, treatment for perianal disease will align with fistulizing disease, as these patients are prone to get perianal fistulas due to disease and inflammation. Like fistulizing disease, treatment has included antibiotics, immunotherapies, and anti-TNF medication (infliximab) and surgery. Unfortunately, the results and outcomes are usually frustrating for patients and physicians with disease reoccurrence occurring. Hence, there is a need for research in future treatments, such as stem cells, which will provide improved healing and continued remission of disease; an outline of these studies and treatment modality types is shown in Table 3.

\section{Autologous adipose tissue-derived stem cell therapy trials}

In 2005 Garcia-Olmo et al performed a Phase I clinical trial with split complex refractory CD fistulas which were refractory to medical and surgical therapy. ${ }^{47}$ Patients had local injections of $3 \times 10^{6} \mathrm{MSC}$. There were $75 \%$ ( 3 of 4 ) of patients at 8 weeks who achieved tissue repair with no adverse events seen after 2 years follow-up. These authors continue their studies with a Phase IIb clinical trial in 2009 where patients with complex perianal cryptoglandular $(n=35)$ and CD fistulas $(n=14)$ all refractory to medical and surgical therapy underwent local injection with either $2 \times 10^{6}$ autoASC plus fibrin glue vs fibrin glue alone. If patients were not responsive with healing at 8 weeks, they were given a second injection at the site of fistula with $4 \times 10^{6}$ autoASC..$^{17,48}$ Overall quality of life was improved in the autoASC plus fibrin glue group. Results of the study showed $71 \%$ (17 of 24) of patients with combination therapy, in comparison with $16 \%$ (4 of 25 ) of patients with solo fibrin glue therapy, attained fistula healing $(P<0.001)$. 
Table 3 Overview of stem cell studies for treatment with patients having perianal disease

\begin{tabular}{|c|c|c|c|c|c|c|}
\hline Author & Date & $\begin{array}{l}\text { Stem cell } \\
\text { type }\end{array}$ & $\begin{array}{l}\text { Treatment } \\
\text { location }\end{array}$ & $\begin{array}{l}\text { Study } \\
\text { type }\end{array}$ & Patients (n) & Results \\
\hline $\begin{array}{l}\text { Garcia- } \\
\text { Olmo } \\
\text { et al }{ }^{47}\end{array}$ & 2005 & $\begin{array}{l}\text { Autologous } \\
\text { adipose } \\
\text { tissue }\end{array}$ & Perianal & $\begin{array}{l}\text { Prospective } \\
\text { Phase I }\end{array}$ & 4 & $\begin{array}{l}75 \% \text { tissue repair at week } 8 \text { with } \\
\text { no recurrence or adverse events } \\
\text { at } 2 \text { years }\end{array}$ \\
\hline $\begin{array}{l}\text { Garcia- } \\
\text { Olmo } \\
\text { et } \mathrm{al}^{48}\end{array}$ & 2009 & $\begin{array}{l}\text { Autologous } \\
\text { adipose } \\
\text { tissue }\end{array}$ & $\begin{array}{l}\text { Perianal/ } \\
\text { fistulizing }\end{array}$ & $\begin{array}{l}\text { Prospective } \\
\text { Phase Ilb }\end{array}$ & $\begin{array}{l}\text { CD fistulas } 14 \\
\text { Perianal } \\
\text { cryptoglandular } 35\end{array}$ & $\begin{array}{l}71 \% \text { combination therapy of MSC } \\
\text { plus fibrin glue vs } 16 \% \text { fibrin-alone } \\
\text { healing }\end{array}$ \\
\hline $\begin{array}{l}\text { Guadalajara } \\
\text { et } \mathrm{al}^{49}\end{array}$ & 2012 & $\begin{array}{l}\text { Autologous } \\
\text { adipose } \\
\text { tissue }\end{array}$ & $\begin{array}{l}\text { Perianal/ } \\
\text { fistulizing }\end{array}$ & $\begin{array}{l}\text { Prospective } \\
\text { Phase II }\end{array}$ & $\begin{array}{l}\text { CD } 8 \text { (5 } \\
\text { combination and } 3 \\
\text { solely glue) } \\
\text { Cryptoglandular } 13 \\
\end{array}$ & $\begin{array}{l}\text { Complete healing } 57.1 \% \\
\text { combination treatment and } 23 \% \\
\text { solely glue }\end{array}$ \\
\hline Park et $\mathrm{al}^{42}$ & 2016 & $\begin{array}{l}\text { Allogeneic } \\
\text { adipose } \\
\text { tissue }\end{array}$ & Perianal & $\begin{array}{l}\text { Prospective } \\
\text { pilot study }\end{array}$ & 6 & $\begin{array}{l}\text { Complete healing in } 16.7 \% \text { patients } \\
\text { at } 8 \text { weeks and } 50 \% \text { at } 8 \text { months } \\
\text { No related adverse events }\end{array}$ \\
\hline
\end{tabular}

Abbreviations: CD, Crohn's disease; MSC, mesenchymal stem cells.

In 2011, a follow-up study was done by this group evaluating patients from the Phase II study above in a retrospective follow-up. ${ }^{49}$ In the Phase II study, 24 patients were treated with autoASC plus fibrin glue and 21 were included in retrospective analysis, whereas 25 patients were treated with fibrin glue alone in the Phase II trial and 13 were recruited for follow-up. Only eight patients in the retrospective analysis were $\mathrm{CD}$ patients composed of five autoASC plus fibrin glue and three solely fibrin glue, with the rest of the subjects having non-IBD fistulas. Patients were a relative equal composite of males and females with complex perianal and rectovaginal fistulas. Results of this study showed complete closure in 12 of 21 patients with autoASC plus fibrin glue and 3 of 13 with only fibrin glue. The authors concluded this treatment was safe as no neoplastic outcomes were seen after 4 years. Also, none of this small patient population experienced fecal incontinence.

\section{Conclusion}

Clearly, a significant amount of research has been published over the last several years evaluating stem cell therapy for IBD. Many different types of stem cell treatments have been evaluated, including HSCT and MSC (both bone-marrow derived and adipose-derived), and autologous or allogeneic. There have been some reports of adverse events, and for the most part, these are not clinically serious.

Challenges for stem cell therapy include those similar to autologous or allogeneic transplantation. A common challenge for most studies is patient recruitment, which appears to be the main reason for most studies analyzing stem cell therapy for IBD according to ClinicalTrials.gov. An overview of these terminated or withdrawn trials can be seen in Table 4. Availability of locations to either store or harvest stem cells, personnel trained and experienced to collect and administer cells in a safe and appropriate manner thus limiting adverse events such as infection or pain, access to care, and payment affordability are all future barriers to care for this patient population. Fortunately, these therapies have largely been found to be both safe and effective for many individuals afflicted with luminal, perianal, or fistulizing CD that is refractory to standard medical and surgical management and the current literature for using treatment is optimistic.

For luminal disease in IBD patients alloHSCT is not recommended due to high risk of side effects and mortality with treatment, and because of this, studies are not being conducted for this treatment modality. Patients with autoHSCT have to undergo pretreatment for mobilization with agents such as CTX and G-CSF predisposing them to infection and thus requiring other supportive agents such as ciprofloxacin and fluconazole. All studies using autoHSCT for luminal disease showed promising outcomes; however, patient populations were very small ranging from 3 to 48 . Patients with luminal disease experienced remission $45 \%-100 \%$ of the time after 6 months and showed continued remission $70 \%-100 \% 4-5$ years out. Unfortunately, these patients treated with autoHSCT were seen to experience infections, and less commonly (39\%), GVHD. While patients treated with autoBM-MSC or alloBM-MSC did not have larger populations than autoHSCT, they did not experience as frequent adverse events. These two groups, however, did not show impressive treatment outcomes with only $38 \%-55 \%$ of patients with either clinical or CDAI improvement. 
Table 4 Stem cell clinical trials withdrawn or terminated for inflammatory bowel disease

\begin{tabular}{|c|c|c|c|c|c|}
\hline $\begin{array}{l}\text { ClinicalTrials. } \\
\text { gov identifier }\end{array}$ & $\begin{array}{l}\text { Principal } \\
\text { investigator/ } \\
\text { Sponsors }\end{array}$ & Study title & Year(s) & $\begin{array}{l}\text { Terminated } \\
\text { or } \\
\text { withdrawn }\end{array}$ & $\begin{array}{l}\text { Reason for } \\
\text { termination/ } \\
\text { withdrawal }\end{array}$ \\
\hline NCT0I85I343 & $\begin{array}{l}\text { Ivan J Fuss, MD, } \\
\text { National Institute } \\
\text { of Allergy and } \\
\text { Infectious Diseases } \\
\text { (NIAID) }\end{array}$ & $\begin{array}{l}\text { An Open-Label, } \\
\text { Phase I Study to } \\
\text { Assess the Safety } \\
\text { and Tolerability } \\
\text { of Bone Marrow } \\
\text { Stromal Cell } \\
\text { Infusion for the } \\
\text { Treatment of } \\
\text { Moderate to Severe } \\
\text { Inflammatory Bowel } \\
\text { Disease }\end{array}$ & $2013-2017$ & Terminated & $\begin{array}{l}\text { Difficulty } \\
\text { with patient } \\
\text { recruitment }\end{array}$ \\
\hline NCT0027I947 & $\begin{array}{l}\text { Robert Craig, MD, } \\
\text { Northwestern } \\
\text { University }\end{array}$ & $\begin{array}{l}\text { Crohn's Disease } \\
\text { Non-myeloablative } \\
\text { Autologous } \\
\text { Hematopoietic } \\
\text { Stem Cell } \\
\text { Transplantation } \\
\text { (CDNST) Versus } \\
\text { Standard Therapy }\end{array}$ & $2005-2013$ & Terminated & $\begin{array}{l}\text { Principal } \\
\text { Investigator } \\
\text { who was } \\
\text { sponsor } \\
\text { retired }\end{array}$ \\
\hline NCT0I 288053 & $\begin{array}{l}\text { Richard Burt, MD, } \\
\text { Northwestern } \\
\text { University }\end{array}$ & $\begin{array}{l}\text { Non-myeloablative } \\
\text { Allogeneic } \\
\text { Hematopoietic } \\
\text { Stem Cell } \\
\text { Transplantation } \\
\text { (NST) for Patients } \\
\text { With Refractory } \\
\text { Crohn's Disease }\end{array}$ & $2010-2016$ & Terminated & $\begin{array}{l}\text { "No } \\
\text { participant } \\
\text { enrolled more } \\
\text { than two } \\
\text { years. No plan } \\
\text { to continue } \\
\text { study." }\end{array}$ \\
\hline NCT0I932658 & $\begin{array}{l}\text { Daniel W Hommes, } \\
\text { MD, PhD, } \\
\text { University of } \\
\text { California, Los } \\
\text { Angeles }\end{array}$ & $\begin{array}{l}\text { Autologous } \\
\text { Hematopoietic } \\
\text { Stem Cell } \\
\text { Transplantation for } \\
\text { Crohn's Disease } \\
\text { Treatment }\end{array}$ & $2014-2016$ & Withdrawn & $\begin{array}{l}\text { Patients' } \\
\text { insurance } \\
\text { would not } \\
\text { cover the cost } \\
\text { of the study } \\
\text { procedures }\end{array}$ \\
\hline NCT02225795 & $\begin{array}{l}\text { Haydar Frangoul, MD, } \\
\text { TriStar Health }\end{array}$ & $\begin{array}{l}\text { A Pilot Study } \\
\text { of Autologous } \\
\text { Hematopoietic } \\
\text { Stem Cell } \\
\text { Transplantation } \\
\text { With Post- } \\
\text { transplant } \\
\text { Cyclophosphamide } \\
\text { for Children and } \\
\text { Young Adults With } \\
\text { Refractory Crohn's } \\
\text { Disease }\end{array}$ & $2014-2018$ & Withdrawn & $\begin{array}{l}\text { Difficulty } \\
\text { with patient } \\
\text { recruitment }\end{array}$ \\
\hline NCT02676622 & $\begin{array}{l}\text { Sandeep Soni, MD, } \\
\text { Nationwide } \\
\text { Children's Hospital }\end{array}$ & $\begin{array}{l}\text { A Pilot Study } \\
\text { of Autologous } \\
\text { Hematopoietic } \\
\text { Stem Cell } \\
\text { Transplantation } \\
\text { With Post- } \\
\text { Transplant Ultra } \\
\text { Low-Dose IL-2 for } \\
\text { Refractory Crohn's } \\
\text { Disease }\end{array}$ & 2013 & Withdrawn & $\begin{array}{l}\text { Principal } \\
\text { Investigator } \\
\text { moved to } \\
\text { a different } \\
\text { institution }\end{array}$ \\
\hline
\end{tabular}

(Continued) 
Table 4 (Continued)

\begin{tabular}{|c|c|c|c|c|c|}
\hline $\begin{array}{l}\text { ClinicalTrials. } \\
\text { gov identifier }\end{array}$ & $\begin{array}{l}\text { Principal } \\
\text { investigatorl } \\
\text { Sponsors }\end{array}$ & Study title & Year(s) & $\begin{array}{l}\text { Terminated } \\
\text { or } \\
\text { withdrawn }\end{array}$ & $\begin{array}{l}\text { Reason for } \\
\text { termination/ } \\
\text { withdrawal }\end{array}$ \\
\hline NCT00I79842 & $\begin{array}{l}\text { Morris Kletzel, MD, } \\
\text { Ann \& Robert H. } \\
\text { Lurie, Children's } \\
\text { Hospital of Chicago }\end{array}$ & $\begin{array}{l}\text { Immune Ablation } \\
\text { and Hematopoietic } \\
\text { Stem Cell Support } \\
\text { in Patients With } \\
\text { Severe Crohn's } \\
\text { Disease }\end{array}$ & 2005-2008 & Withdrawn & $\begin{array}{l}\text { Not indicated } \\
\text { why }\end{array}$ \\
\hline NCTOI 378390 & $\begin{array}{l}\text { Damián García- } \\
\text { Olmo, MD, } \\
\text { General Surgery } \\
\text { Department, Hospital } \\
\text { Universitario La Paz }\end{array}$ & $\begin{array}{l}\text { Randomized, } \\
\text { Single-blind, } \\
\text { Placebo Controlled } \\
\text { Multicenter Phase } \\
\text { III Study to Assess } \\
\text { the Efficacy and } \\
\text { Safety of Expanded } \\
\text { Autologous } \\
\text { Adipose-derived } \\
\text { Stem Cells (ASCs) } \\
\text { (CX-40I), for } \\
\text { Treatment of } \\
\text { Complex Perianal } \\
\text { Fistulas in Perianal } \\
\text { Crohn's Disease }\end{array}$ & $2008-2010$ & Terminated & $\begin{array}{l}\text { "After the } \\
\text { investigators } \\
\text { and experts } \\
\text { in the field's } \\
\text { input it } \\
\text { became } \\
\text { apparent the } \\
\text { protocol was } \\
\text { not reflective } \\
\text { of clinical } \\
\text { reality. No } \\
\text { safety issues } \\
\text { reported." }\end{array}$ \\
\hline
\end{tabular}

In comparison with luminal disease, stem cell therapy is more promising for both fistulizing and perianal disease treatment. While several studies for fistulizing disease also have smaller patient populations, several studies have 30-80 patients. Only two studies utilizing bone marrow were done for fistulizing disease - one autoBM-MSC and the other alloBM-MSC. Overall, autoASC treatment showed $75 \%-83 \%$ resolution of fistulas, many after one dose of local injection, and 33\%-89\% continued remission after 6 months to a year. Those studies that used autoASC and another treatment such as fibrin glue did not have as successful results for resolution with $57 \%-71 \%$. In the four studies that used alloASC treatment for fistulizing disease in IBD patients, results were encouraging. Fifty to ninety percent of patients had resolution of their fistulas at 6 months to a year with continued resolution seen at around 50\% 1 year from administration. Given that administration of biologic therapy is a long-term commitment and has more reported adverse events with only a $50 \%$ resolution and common reoccurrence of fistulas, autoASC or alloASC are exciting treatment options for patients with fistulizing disease. Based on this review, patients should be educated on the ability to have autoASC or alloASC treatment options for fistulizing disease, or at least consultation for possible enrollment in future clinical trials.

Perianal disease has overlap with fistulizing disease. Two of the four studies using stem cell therapy looked at both perianal and fistulizing outcomes and are also included in the above discussion. AutoASC studies for perianal disease is more common with three of the four studies being conducted utilizing this treatment option. Like fistulizing disease results, perianal disease shows resolution in $57 \%-75 \%$ of patients, and two of the studies also included fibrin glue for treatment. AlloASC only had one study with a small patient population (six patients) and so conclusions by the authors cannot be drawn. It would be recommended that autoASC be offered to patients with perianal disease as stated with fistulizing disease as to date it appears to be safe and effective per this review data.

Certainly, many more studies need to be performed to further understand the utility of stem cell treatment weighed against its risks for the management of medically and surgically refractory IBD. This is evident per the medical and scientific community with 19 studies enrolling or about to enroll patients for trials of stem cell therapy in patients with IBD. An outline of these studies can be seen in Table 5. Addi- 
Table 5 Stem cell clinical trials on the horizon for inflammatory bowel disease

\begin{tabular}{|c|c|c|c|c|c|}
\hline $\begin{array}{l}\text { ClinicalTrials. } \\
\text { gov identifier }\end{array}$ & $\begin{array}{l}\text { Principal } \\
\text { investigatorl } \\
\text { Sponsors }\end{array}$ & Study title & $\begin{array}{l}\text { Type of } \\
\text { study }\end{array}$ & Condition & Status \\
\hline NCT032994I3 & $\begin{array}{l}\text { Hanan Jafar, DDS, } \\
\text { MSc, PhD, University } \\
\text { of Jordan }\end{array}$ & $\begin{array}{l}\text { Ulcerative Colitis Stem Cell } \\
\text { Therapy }\end{array}$ & $\begin{array}{l}\text { Single group, } \\
\text { Phase } \mathrm{I} / \mathrm{Il}, \\
\text { open label, } \\
\text { clinical trial }\end{array}$ & IBD & $\begin{array}{l}\text { Recruiting } \\
\text { (estimated } \\
\mathrm{n}=20 \text { ) }\end{array}$ \\
\hline NCT02874365 & $\begin{array}{l}\text { Emmanuel MAS, MD, } \\
\text { PhD, } \\
\text { University Hospital, } \\
\text { Toulouse }\end{array}$ & $\begin{array}{l}\text { Intestinal stem cells } \\
\text { characterization in intestinal } \\
\text { organoid culture from } \\
\text { inflammatory bowel disease and } \\
\text { intestinal polyposis patients }\end{array}$ & $\begin{array}{l}\text { Parallel, } \\
\text { open label, } \\
\text { clinical trial }\end{array}$ & IBD & $\begin{array}{l}\text { Recruiting } \\
\text { (estimated } \\
\mathrm{n}=120 \text { ) }\end{array}$ \\
\hline NCT03II5749 & $\begin{array}{l}\text { Guillaume Pineton, MD, } \\
\text { University Hospital, } \\
\text { Montpellier }\end{array}$ & $\begin{array}{l}\text { Characterization of mesenchymal } \\
\text { stem cell from the colon and } \\
\text { small intestine of patients with } \\
\text { inflammatory bowel disease - the } \\
\text { COSMIC study }\end{array}$ & $\begin{array}{l}\text { Parallel, } \\
\text { open label }\end{array}$ & IBD & $\begin{array}{l}\text { Not yet } \\
\text { recruiting } \\
\text { (estimated } \\
\mathrm{n}=60 \text { ) }\end{array}$ \\
\hline NCT03000296 & $\begin{array}{l}\text { Milton A Ruiz, MD, } \\
\text { PhD, } \\
\text { Beneficencia } \\
\text { Portuguesa }\end{array}$ & $\begin{array}{l}\text { Autologous unselected } \\
\text { hematopoietic stem cell } \\
\text { transplantation for refractory } \\
\text { Crohn's Disease }\end{array}$ & $\begin{array}{l}\text { Single group, } \\
\text { open label }\end{array}$ & CD/IBD & $\begin{array}{l}\text { Recruiting } \\
\text { (estimated } \\
\mathrm{n}=50 \text { ) }\end{array}$ \\
\hline NCT03369353 & $\begin{array}{l}\text { Leslie Kean, MD, } \\
\text { PhD, Seattle } \\
\text { Children's Hospital }\end{array}$ & $\begin{array}{l}\text { Precision diagnostics } \\
\text { in inflammatory bowel } \\
\text { disease, cellular therapy and } \\
\text { transplantation (the PREDICT } \\
\text { trial) }\end{array}$ & $\begin{array}{l}\text { Prospective, } \\
\text { observational } \\
\text { cohort }\end{array}$ & IBD & $\begin{array}{l}\text { Enrolling } \\
\text { by } \\
\text { invitation } \\
\text { (estimated } \\
\mathrm{n}=625 \text { ) }\end{array}$ \\
\hline NCT03219359 & $\begin{array}{l}\text { Amir Steinberg, MD, } \\
\text { Icahn School of } \\
\text { Medicine at Mount } \\
\text { Sinai } \\
\text { Louis Cohen, MD, } \\
\text { Icahn School of } \\
\text { Medicine at Mount } \\
\text { Sinai }\end{array}$ & $\begin{array}{l}\text { Maintenance in autologous stem } \\
\text { cell transplant for Crohn's disease } \\
\text { (MASCT - CD) }\end{array}$ & $\begin{array}{l}\text { Single group, } \\
\text { Phase II, } \\
\text { open label }\end{array}$ & $C D$ & $\begin{array}{l}\text { Recruiting } \\
\text { (estimated } \\
\mathrm{n}=50 \text { ) }\end{array}$ \\
\hline NCT02677350 & $\begin{array}{l}\text { David Kerman, MD, } \\
\text { University of Miami }\end{array}$ & $\begin{array}{l}\text { A Phase I, pilot trial to evaluate } \\
\text { the safety and efficacy of injection } \\
\text { of allogeneic mesenchymal bone- } \\
\text { marrow derived human stem cells } \\
\text { in patients with fistulizing Crohn's } \\
\text { disease }\end{array}$ & $\begin{array}{l}\text { Single group, } \\
\text { Phase I, } \\
\text { open label }\end{array}$ & $C D$ & $\begin{array}{l}\text { Not yet } \\
\text { recruiting }\end{array}$ \\
\hline NCT02000362 & $\begin{array}{l}\text { Suk-Kyun Yang, Asan } \\
\text { Medical Center }\end{array}$ & $\begin{array}{l}\text { An open-labelled, multi center, } \\
\text { comparative Phase I/lla clinical trial } \\
\text { to evaluate the efficacy and safety } \\
\text { of FURESTEM-CD Inj. in patients } \\
\text { with moderately active Crohn's } \\
\text { disease }\end{array}$ & $\begin{array}{l}\text { Single group, } \\
\text { Phase I/Il, } \\
\text { open label }\end{array}$ & $C D$ & $\begin{array}{l}\text { Recruiting } \\
\text { (estimated } \\
\mathrm{n}=24 \text { ) }\end{array}$ \\
\hline NCT00692939 & $\begin{array}{l}\text { Paul Szabolcs, MD, } \\
\text { Children's Hospital of } \\
\text { Pittsburgh of UPMC }\end{array}$ & $\begin{array}{l}\text { Autologous stem cell } \\
\text { transplantation with CD34- } \\
\text { selected peripheral blood stem } \\
\text { cells (PBSC) in pediatric and adult } \\
\text { patients with severe Crohn's } \\
\text { disease }\end{array}$ & $\begin{array}{l}\text { Single Group, } \\
\text { Phase I/II, } \\
\text { open label }\end{array}$ & $C D$ & $\begin{array}{l}\text { Recruiting } \\
\text { (estimated } \\
\mathrm{n}=20 \text { ) }\end{array}$ \\
\hline NCT0I8740I5 & $\begin{array}{l}\text { Massoud Vosough, MD, } \\
\text { PhD, } \\
\text { Royan Institute }\end{array}$ & $\begin{array}{l}\text { Transplantation of bone marrow } \\
\text { mesenchymal stem cell in } \\
\text { moderate to severe fistulizing } \\
\text { Crohn's disease }\end{array}$ & $\begin{array}{l}\text { Parallel, } \\
\text { Phase I } \\
\text { randomized } \\
\text { single } \\
\text { (investigator) }\end{array}$ & $C D$ & $\begin{array}{l}\text { Recruiting } \\
\text { (estimated } \\
\mathrm{n}=10 \text { ) }\end{array}$ \\
\hline
\end{tabular}

(Continued) 
Table 5 (Continued)

\begin{tabular}{|c|c|c|c|c|c|}
\hline $\begin{array}{l}\text { ClinicalTrials. } \\
\text { gov identifier }\end{array}$ & $\begin{array}{l}\text { Principal } \\
\text { investigatorl } \\
\text { Sponsors }\end{array}$ & Study title & $\begin{array}{l}\text { Type of } \\
\text { study }\end{array}$ & Condition & Status \\
\hline NCT02926300 & $\begin{array}{l}\text { Suk-Kyun Yang, Asan } \\
\text { Medical Center }\end{array}$ & $\begin{array}{l}\text { Extension study, an open-labelled, } \\
\text { multi center, comparative Phase I/ } \\
\text { lla clinical trials to evaluate the } \\
\text { efficacy and safety of FURESTEM- } \\
\text { CD Inj. in patients with } \\
\text { moderately active Crohn's disease }\end{array}$ & $\begin{array}{l}\text { Prospective } \\
\text { observational } \\
\text { cohort } \\
\text { (extended } \\
\text { study of } \\
\text { KSTHD_- } \\
\text { FURESTEM- } \\
\text { CD) } \\
\text { Phase I/II a } \\
\text { clinical trial }\end{array}$ & $C D$ & $\begin{array}{l}\text { Recruiting } \\
\text { (estimated } \\
\mathrm{n}=24 \text { ) }\end{array}$ \\
\hline NCT034665I5 & $\begin{array}{l}\text { Karam Matlub, MD, } \\
\text { University of Southern } \\
\text { Denmark }\end{array}$ & $\begin{array}{l}\text { Stem cells treatment of complex } \\
\text { Crohn's perianal fistula. A pilot } \\
\text { clinical study }\end{array}$ & $\begin{array}{l}\text { Single group, } \\
\text { Pilot study, } \\
\text { open label }\end{array}$ & $C D$ & $\begin{array}{l}\text { Recruiting } \\
\text { (estimated } \\
\mathrm{n}=24 \text { ) }\end{array}$ \\
\hline NCT0327908I & $\begin{array}{l}\text { Cellerix (TiGenix } \\
\text { S.A.U.) }\end{array}$ & $\begin{array}{l}\text { Phase-III randomized, double-blind, } \\
\text { parallel-group, placebo-controlled, } \\
\text { multicentre study to assess } \\
\text { efficacy and safety of Cx60I, } \\
\text { allogeneic expanded adipose- } \\
\text { derived stem cells for complex } \\
\text { Perianal Fistula(s) in Crohn's } \\
\text { disease. ADMIRE-CD-II }\end{array}$ & $\begin{array}{l}\text { Parallel, } \\
\text { Phase III, } \\
\text { randomized, } \\
\text { double blind }\end{array}$ & $C D$ & $\begin{array}{l}\text { Recruiting } \\
\text { (estimated } \\
\mathrm{n}=326 \text { ) }\end{array}$ \\
\hline NCT02403232 & $\begin{array}{l}\text { Papa Giovanni XXIII } \\
\text { Hospital }\end{array}$ & $\begin{array}{l}\text { Autologous adipose-derived stem } \\
\text { cells (ASCs) for the treatment of } \\
\text { perianal fistula in Crohn disease: A } \\
\text { Pilot Study }\end{array}$ & $\begin{array}{l}\text { Single group, } \\
\text { Phase II, } \\
\text { open label }\end{array}$ & $C D$ & $\begin{array}{l}\text { Recruiting } \\
\text { (estimated } \\
\mathrm{n}=326 \text { ) }\end{array}$ \\
\hline NCT03I8366I & $\begin{array}{l}\text { Won Ho Kim, PhD, } \\
\text { Yonsei University } \\
\text { Joo Sung Kim, PhD, } \\
\text { Seoul National } \\
\text { University Hospital } \\
\text { Young Ho Kim, PhD, } \\
\text { Samsung Medical } \\
\text { Center }\end{array}$ & $\begin{array}{l}\text { Follow-up study to evaluate the } \\
\text { safety of ALLO-ASC-CD in the } \\
\text { subjects with Crohn's disease } \\
\text { (ALLO-ASC-CD-IOI) }\end{array}$ & $\begin{array}{l}\text { Prospective } \\
\text { observational } \\
\text { case-only }\end{array}$ & $C D$ & $\begin{array}{l}\text { Enrolling } \\
\text { by } \\
\text { invitation } \\
(n=9)\end{array}$ \\
\hline NCT025806I7 & $\begin{array}{l}\text { Won Ho Kim, Yonsei } \\
\text { University }\end{array}$ & $\begin{array}{l}\text { A Phase I clinical study to evaluate } \\
\text { the safety of allogeneic adipose- } \\
\text { derived stem cells in the subjects } \\
\text { with Crohn's disease }\end{array}$ & $\begin{array}{l}\text { Single group, } \\
\text { Phase I, } \\
\text { open label }\end{array}$ & $C D$ & $\begin{array}{l}\text { Recruiting } \\
\text { (estimated } \\
\mathrm{n}=9 \text { ) }\end{array}$ \\
\hline NCT02952I3I & $\begin{array}{l}\text { Robert W Alexander, } \\
\text { MD, Healeon Medical } \\
\text { Inc }\end{array}$ & $\begin{array}{l}\text { Use of autologous adult adipose- } \\
\text { derived stem/stromal cells in } \\
\text { inflammatory bowel disease }\end{array}$ & $\begin{array}{l}\text { Parallel, } \\
\text { Phase I/II, } \\
\text { single } \\
\text { (participant) }\end{array}$ & IBD & $\begin{array}{l}\text { Recruiting } \\
\text { (estimated } \\
\mathrm{n}=100 \text { ) }\end{array}$ \\
\hline NCT03609905 & $\begin{array}{l}\text { Peng Yan, MD, } \\
\text { Liaocheng People's } \\
\text { Hospital }\end{array}$ & $\begin{array}{l}\text { A Phase I/II randomized, } \\
\text { controlled, clinical trial for } \\
\text { assessment of the safety and } \\
\text { efficacy of allogeneic adipose } \\
\text { mesenchymal stem cells in } \\
\text { moderate to severe ulcerative } \\
\text { colitis patients }\end{array}$ & $\begin{array}{l}\text { Parallel, } \\
\text { Phase I/II, } \\
\text { randomized, } \\
\text { double blind } \\
\text { purpose: }\end{array}$ & UC & $\begin{array}{l}\text { Recruiting } \\
\text { (estimated } \\
\mathrm{n}=50 \text { ) }\end{array}$ \\
\hline NCT03220243 & $\begin{array}{l}\text { Amy L Lightner, Mayo } \\
\text { Clinic }\end{array}$ & $\begin{array}{l}\text { A Phase I study of autologous } \\
\text { mesenchymal stromal cell coated } \\
\text { fistula plug in patients with } \\
\text { rectovaginal fistulizing Crohn's } \\
\text { disease }\end{array}$ & $\begin{array}{l}\text { Single group, } \\
\text { Phase I, } \\
\text { open label }\end{array}$ & $C D$ & $\begin{array}{l}\text { Recruiting } \\
\text { (estimated } \\
n=15 \text { ) }\end{array}$ \\
\hline
\end{tabular}

Abbreviations: CD, Crohn's disease; IBD, Inflammatory bowel disease; UC, ulcerative colitis. 
tionally, a large Phase III, placebo-controlled, double-blinded study known as PROCHYMAL has just been completed. ${ }^{50}$ However, results have not been published. This study has a total of 200 patients with three arms including a placebo group, a low-dose group (600 million cells) and a high-dose group (1,200 million cells) of which these were administered IV four times over a week with possibility of repeating depending on results. Patients' benefits will be evaluated up through 6 months. Patients had to participate in the Osiris Therapeutics companies prior studies using PROCHYMAL, which has also not been released yet, and show CDAI $<100$ at day 28 of the trial. Hopefully, over the course of the next decade, promising modalities like these will have come to fruition and stem cell therapy may be a viable treatment option for those with difficult-to-control UC and CD.

\section{Author contributions}

All authors contributed to data analysis, drafting or revising the article, gave final approval of the version to be published, and agree to be accountable for all aspects of the work.

\section{Disclosure}

The authors report no conflicts of interest in this work.

\section{References}

1. Irhimeh MR, Cooney J. Management of inflammatory bowel disease using stem cell therapy. Curr Stem Cell Res Ther. 2016;11(1):72-77.

2. Holmberg FEO, Pedersen J, Jørgensen P, Soendergaard C, Jensen KB, Nielsen $\mathrm{OH}$. Intestinal barrier integrity and inflammatory bowel disease: stem cell-based approaches to regenerate the barrier. JTissue Eng Regen Med. 2018;12(4):923-935.

3. Flores AI, Gómez-Gómez GJ, Masedo-González Á, Martínez-Montiel MP. Stem cell therapy in inflammatory bowel disease: a promising therapeutic strategy? World J Stem Cells. 2015;7(2):343-351.

4. Uhlig HH, Schwerd T, Koletzko S, et al. The diagnostic approach to monogenic very early onset inflammatory bowel disease. Gastroenterology. 2014;147(5):990-1007.

5. Qiu X, Feng JR, Chen LP, et al. Efficacy and safety of autologous hematopoietic stem cell therapy for refractory Crohn's disease: a systematic review and meta-analysis. Medicine. 2017;96(26):e7381.

6. Snowden JA, Panés J, Alexander T, et al. Autologous haematopoietic stem cell transplantation (AHSCT) in severe Crohn's disease: a review on behalf of ECCO and EBMT. J Crohns Colitis. 2018;12(4):476-488.

7. Drakos PE, Nagler A, Or R. Case of Crohn's disease in bone marrow transplantation. Am J Hematol. 1993;43(2):157-158.

8. Oyama Y, Craig RM, Traynor AE, et al. Autologous hematopoietic stem cell transplantation in patients with refractory Crohn's disease. Gastroenterology. 2005;128(3):552-563.

9. Cassinotti A, Annaloro C, Ardizzone S, et al. Autologous haematopoietic stem cell transplantation without CD34+ cell selection in refractory Crohn's disease. Gut. 2008;57(2):211-217.

10. Burt RK, Craig RM, Milanetti F, et al. Autologous nonmyeloablative hematopoietic stem cell transplantation in patients with severe anti-TNF refractory Crohn disease: long-term follow-up. Blood. 2010;116(26):6123-6132.
11. Hommes DW, Duijvestein M, Zelinkova Z, et al. Long-term follow-up of autologous hematopoietic stem cell transplantation for severe refractory Crohn's disease. J Crohns Colitis. 2011;5(6):543-549.

12. Hasselblatt P, Drognitz K, Potthoff K, et al. Remission of refractory Crohn's disease by high-dose cyclophosphamide and autologous peripheral blood stem cell transplantation. Aliment Pharmacol Ther. 2012;36(8):725-735.

13. Snowden JA, Saccardi R, Allez M, Ardizzone S, Arnold R, Cervera $\mathrm{R}$ et al. Haematopoietic SCT in severe autoimmune diseases: updated guidelines of the European Group for Blood and Marrow Transplantation. Bone Marrow Transpl. 2011;47(6):770-790.

14. Snowden JA, Ansari A, Sachchithanantham S, et al. Autologous stem cell transplantation in severe treatment-resistant Crohn's disease: longterm follow-up of UK patients treated on compassionate basis. QJM. 2014;107(11):871-877.

15. Jauregui-Amezaga A, Rovira M, Marín P, et al. Improving safety of autologous haematopoietic stem cell transplantation in patients with Crohn's disease. Gut. 2016;65(9):1456-1462.

16. López-García A, Rovira M, Jauregui-Amezaga A, et al. Autologous haematopoietic stem cell transplantation for refractory Crohn's disease: efficacy in a single-centre cohort. J Crohns Colitis. 2017;11(10):1161-1168.

17. Hawkey CJ, Allez M, Clark MM, et al. Autologous hematopoetic stem cell transplantation for refractory Crohn disease: a randomized clinical trial. JAMA. 2015;314(23):2524-2534.

18. Lindsay JO, Allez M, Clark M, et al. Autologous stem-cell transplantation in treatment-refractory Crohn's disease: an analysis of pooled data from the ASTIC trial. Lancet Gastroenterol Hepatol. 2017;2(6):399-406.

19. Rabian F, Porcher R, Sicre de Fontbrune F, et al. Influence of previous inflammatory bowel disease on the outcome of allogeneic hematopoietic stem cell transplantation: a matched-pair analysis. Biol Blood Marrow Transplant. 2016;22(9):1721-1724.

20. Onken J, Gallup D, Hanson J, Pandak M, Custer L. Successful Outpatient Treatment of Refractory Crohn's Disease Using Adult Mesenchymal Stem Cells. 71st Annual Scientific Meeting of the American College of Gastroenterology. October 20-25, 2006, Las Vegas, Nevada, USA. Abstract 121.

21. Duijvestein M, Vos AC, Roelofs H, et al. Autologous bone marrowderived mesenchymal stromal cell treatment for refractory luminal Crohn's disease: results of a phase I study. Gut. 2010;59(12):1662-1669.

22. Dhere T, Copland I, Garcia M, et al. The safety of autologous and metabolically fit bone marrow mesenchymal stromal cells in medically refractory Crohn's disease - a phase 1 trial with three doses. Aliment Pharmacol Ther. 2016;44(5):471-481.

23. Liang J, Zhang H, Wang D, et al. Allogeneic mesenchymal stem cell transplantation in seven patients with refractory inflammatory bowel disease. Gut. 2012;61(3):468-469.

24. Forbes GM, Sturm MJ, Leong RW, et al. A phase 2 study of allogeneic mesenchymal stromal cells for luminal Crohn's disease refractory to biologic therapy. Clin Gastroenterol Hepatol. 2014;12(1):64-71.

25. Mayer L, Pandak WM, Melmed GY, et al. Safety and tolerability of human placenta-derived cells (PDA001) in treatment-resistant Crohn's disease: a phase 1 study. Inflamm Bowel Dis. 2013;19(4): 754-760.

26. Melmed GY, Pandak WM, Casey K, et al. Human placenta-derived cells (PDA-001) for the treatment of moderate-to-severe Crohn's disease: a Phase 1b/2a Study. Inflamm Bowel Dis. 2015;21(8):1809-1816.

27. Hu J, Zhao G, Zhang L, et al. Safety and therapeutic effect of mesenchymal stem cell infusion on moderate to severe ulcerative colitis. Exp Ther Med. 2016;12(5):2983-2989.

28. Zhang J, Lv S, Liu X, Song B, Shi L. Umbilical cord mesenchymal stem cell treatment for Crohn's disease: a randomized controlled clinical trial. Gut Liver. 2018;12(1):73-78.

29. Ditschkowski M, Einsele H, Schwerdtfeger R, et al. Improvement of inflammatory bowel disease after allogeneic stem-cell transplantation. Transplantation. 2003;75(10):1745-1747. 
30. Molendijk I, Bonsing BA, Roelofs H, et al. Allogeneic bone marrowderived mesenchymal stromal cells promote healing of refractory perianal fistulas in patients with Crohn's disease. Gastroenterology. 2015;149(4):918-927.

31. Panes J. Stem cell therapy for perianal fistulas in Crohn's disease. Gastroenterol Hepatol. 2016;12(10):637-640.

32. De Francesco F, Romano M, Zarantonello L, et al. The role of adipose stem cells in inflammatory bowel disease: from biology to novel therapeutic strategies. Cancer Biol Ther. 2016;17(9):889-898.

33. Dothel G, Raschi E, Rimondini R, De Ponti F. Mesenchymal stromal cell-based therapy: regulatory and translational aspects in gastroenterology. World J Gastroenterol. 2016;22(41):9057-9068.

34. Cho YB, Park KJ, Yoon SN, et al. Long-term results of adipose-derived stem cell therapy for the treatment of Crohn's fistula. Stem Cells Transl Med. 2015;4(5):532-537.

35. Cho YB, Lee WY, Park KJ, Kim M, Yoo HW, Yu CS. Autologous adipose tissue-derived stem cells for the treatment of Crohn's fistula: a phase I clinical study. Cell Transplant. 2013;22(2):279-285.

36. Lee WY, Park KJ, Cho YB, et al. Autologous adipose tissue-derived stem cells treatment demonstrated favorable and sustainable therapeutic effect for Crohn's fistula. Stem Cells. 2013;31(11):2575-2581.

37. Dietz AB, Dozois EJ, Fletcher JG, et al. Autologous mesenchymal stem cells, applied in a bioabsorbable matrix, for treatment of perianal fistulas in patients with Crohn's disease. Gastroenterology. 2017;153(1): 59-62.

38. Ciccocioppo R, Gallia A, Sgarella A, Kruzliak P, Gobbi PG, Corazza GR. Long-term follow-up of Crohn disease fistulas after local injections of bone marrow-derived mesenchymal stem cells. Mayo Clin Proc. 2015;90(6):747-755.

39. Ciccocioppo R, Bernardo ME, Sgarella A, et al. Autologous bone marrow-derived mesenchymal stromal cells in the treatment of fistulising Crohn's disease. Gut. 2011;60(6):788-798.

40. García-Arranz M, Herreros MD, González-Gómez C, et al. Treatment of Crohn's-related rectovaginal fistula with allogeneic expanded-adipose derived stem cells: a Phase I-IIa clinical trial. Stem Cells Transl Med 2016;5(11):1441-1446.
41. de La Portilla F, Alba F, García-Olmo D, Herrerías JM, González FX, Galindo A. Expanded allogeneic adipose-derived stem cells (eASCs) for the treatment of complex perianal fistula in Crohn's disease: results from a multicenter phase I/IIa clinical trial. Int J Colorectal Dis. 2013;28(3):313-323.

42. Park KJ, Ryoo SB, Kim JS, et al. Allogeneic adipose-derived stem cells for the treatment of perianal fistula in Crohn's disease: a pilot clinical trial. Colorectal Dis. 2016;18(5):468-476.

43. Panés J, García-Olmo D, van Assche G, et al. Expanded allogeneic adipose-derived mesenchymal stem cells (Cx601) for complex perianal fistulas in Crohn's disease: a phase 3 randomised, double-blind controlled trial. Lancet. 2016;388(10051):1281-1290.

44. Panés J, García-Olmo D, Van Assche G, et al. Long-term efficacy and safety of stem cell therapy (Cx601) for complex perianal fistulas in patients with Crohn's disease. Gastroenterology. 2018;154(5):1334-1342.

45. Wainstein C, Quera R, Fluxá D, et al. Stem cell therapy in refractory perineal Crohn's disease: long-term follow-up. Colorectal Dis. 2018;20(3):O68-O75.

46. Sanz-Baro R, García-Arranz M, Guadalajara H, de la Quintana P, Herreros MD, García-Olmo D. First-in-Human Case Study: pregnancy in women with Crohn's perianal fistula treated with adipose-derived stem cells: a safety study. Stem Cells Transl Med. 2015;4(6):598-602.

47. García-Olmo D, García-Arranz M, Herreros D, Pascual I, Peiro C, Rodríguez-Montes JA. A phase I clinical trial of the treatment of Crohn's fistula by adipose mesenchymal stem cell transplantation. Dis Colon Rectum. 2005;48(7):1416-1423.

48. Garcia-Olmo D, Herreros D, Pascual I, et al. Expanded adipose-derived stem cells for the treatment of complex perianal fistula: a phase II clinical trial. Dis Colon Rectum. 2009;52(1):79-86.

49. Guadalajara H, Herreros D, De-La-Quintana P, Trebol J, Garcia-Arranz M, Garcia-Olmo D. Long-term follow-up of patients undergoing adipose-derived adult stem cell administration to treat complex perianal fistulas. Int J Colorectal Dis. 2012;27(5):595-600.

50. Extended Evaluation of PROCHYMAL ${ }^{\circledR}$ Adult Human Stem Cells for Treatment-Resistant Moderate-to-Severe Crohn's Disease - Full Text View. Full Text View - ClinicalTrials.gov. Available from: https://clinicaltrials.gov/ct2/show/NCT00543374. Accessed September 24, 2018.
Stem Cells and Cloning: Advances and Applications

\section{Publish your work in this journal}

Stem Cells and Cloning: Advances and Applications is an international peer-reviewed, open access journal. Areas of interest in stem cell research include: Embryonic cell stems; Adult stem cells; Blastocysts; Cordblood stem cells; Stem cell transformation and culture; Therapeutic cloning; Umbilical cord blood and bone marrow cells; Laboratory,

\section{Dovepress}

animal and human therapeutic studies; Philosophical and ethical issues related to stem cell research. This journal is indexed on CAS. The manuscript management system is completely online and includes a quick and fair peer-review system. Visit http://www.dovepress.com/ testimonials.php to read real quotes from published authors. 